\title{
The Case of variae lectiones in Classical Islamic Jurisprudence: Grammar and the Interpretation of Law
}

\author{
Mustafa Shah \\ (SOAS, London University)
}

\begin{abstract}
:
The qirā ät or variae lectiones represent the vast corpus of Qur änic readings that were preserved through the historical processes associated with the textual codification and transmission of the Qur än. Despite the fact that differences among certain concomitant readings tend to be nominal, others betray semantic nuances that are brought into play within legal discourses. Both types of readings remain important sources for the history of the text of the Qur'an and early Arabic grammatical thought. While some recent scholars have questioned the historical function and nature of the corpus of qirā āt, others have argued that specific types of variant readings were the resultant products of attempts to circumvent legal inconsistencies which were found in text of the Qur än or were generated through legal debates. Following a preliminary review of the historical framework of the genesis of qirā ät through reference to early grammatical literature, an attempt will be made to shed some light on the role that semantic variation among concomitant readings played in the synthesis and interpretation of law. The aim will be to draw attention to the subtle theoretical frameworks employed by jurists for their contextualization and analysis. This will also include a review of attitudes towards the forms of qirā ät that classical scholarship designated as being anomalous or shädhdha.
\end{abstract}

Key words: qirā ät, variae lectiones; interpretation of law and the Qur ān; grammar; classical Islamic legal discourses; shädhdha

\section{Historical Context}

Constellated around the skeletal text of the Qur'ān, the body of qira ' $\bar{a} t$ (sing. qir $\bar{a}{ }^{\prime} a$ ) or variae lectiones represent the integrated corpus of Qur'annic readings that were viewed in the traditional sources as being preserved through the protracted processes associated with the textual codification and transmission of the Qur'ān. ${ }^{1}$ These sources intimate that while the Qur'ān was the subject of exploratory textual editions by his predecessors, the caliphs Abū 
This is the Accepted Version of an article published by Springer in International Journal for the Semiotics of Law - Revue internationale de Sémiotique juridique June 2016, Volume 29, Issue 2, pp 285-311. Please refer to published version when citing, available at: $10.1007 / \mathrm{s} 11196-016-9461-1$

Accepted Version downloaded from SOAS Research Online: http://eprints.soas.ac.uk/22374/

Bakr (d. 13/634) and 'Umar (d. 23/644), it was the third caliph 'Uthmān who eventually set in motion the process of producing a definitive edition of the text, establishing an editorial committee led by the Companion Zayd ibn Thābit (d. 32/652-3) to oversee the collection. ${ }^{2}$ Still, the same narratives recount that having collated texts originally transcribed on palm-leaf stalks, scattered parchments, shoulder blades, limestone and material preserved in the 'hearts of men', a standardized copy of the Qur'ān was eventually transcribed and skeletal copies of the text were distributed as the standardized version at the behest of the caliph. ${ }^{3}$ The imposition of a canonical version of the Qur'ān is said to have been prompted by concerns about acute differences over the recitation of the text among readers. In one specific prophetic tradition 'Uthmān was implored by a companion to 'save this nation before they descend into disagreement over scripture in the same way the Jews and Christians differed', although opposition to his endeavour is also chronicled in the same sources. ${ }^{4}$ Still, the sources mostly proclaim the efforts of 'Uthmān, confirming that the imposition of a standardised text endures as one of achievements. It was even dramatically exclaimed that had it not been for the endeavour of 'Uthmān and his imposition of a standard text, the community would have turned its attention more so to the recitation of poetry. ${ }^{5}$

Having established a definitive text which was granted the imprimatur of community consensus, the caliph 'Uthmān ordered that eventually existing copies of the Qur'ān which conflicted with the new official version were to be either burnt or shredded; other anecdotes refer to his having them buried. ${ }^{6}$ Reports concerning the number of codices produced by 'Uthmān differ: some state that his committee produced four principal codices: a copy which was sent to Kufa, a copy to Basra, a copy to Damascus, and a copy which was retained at Madinah; in separate reports it is claimed that seven codices were forwarded by the caliph to the various garrison towns. ${ }^{7}$ It is generally accepted that none of the original 'Uthmānic codices has survived, although one often encounters references in the classical literature to scholars' mentioning their having glimpsed the original codices transcribed during the rule of 'Uthmān and their being used as proto-types for the transcription of additional copies; indeed, the Basran philologist Abū 'Ubayd al-Qāsim (d. 224/838) refers to his having seen the codex of 'Uthmān. ${ }^{8}$ The expert on readings and codices, Abū 'Amr alDānī (d. 444/1053), mentions in his al-Muqn̄̄' that the reader 'Āṣim al-Jaḥdarī (d. 130/748) described orthographical conventions that he observed in the 'imām muṣhaf 'Uthmān' and the author himself often intimates that he had seen ancient codices. ${ }^{9}$ Meanwhile, it is reported 
This is the Accepted Version of an article published by Springer in International Journal for the Semiotics of Law - Revue internationale de Sémiotique juridique June 2016, Volume 29, Issue 2, pp 285-311. Please refer to published version when citing, available at: $10.1007 / \mathrm{s} 11196-016-9461-1$

Accepted Version downloaded from SOAS Research Online: http://eprints.soas.ac.uk/22374/

when Mālik ibn Anas (d. 179/795) was asked by Ibn Wahb (d. 197/812) about the whereabouts of 'Uthmān's muṣhaf, he indicated that it was no longer present. ${ }^{10}$ There were among the Companions individuals who are reported to have possessed personal codices: these include 'Abd Allāh ibn Mas'ūd (d. 32/652), Ubayy ibn Ka'b (d. 20/641), Abū Mūsā alAsh 'arī (d. 42/662 or 52/672), Ibn 'Abbās (d. 68/687-8) and Ibn al-Zubayr (d. 73/692), Anas Ibn Mālik (d. c. 93/710-11) and a number of other figures. ${ }^{11}$ In these documented readings there are examples of rather elaborate exegetical interpolations along with selected consonantal and lexical variants which were unquestionably inconsistent with the standardized 'Uthmānic text; classical literature certainly preserves lots of examples of lectiones from these materials which are often discussed in legal, exegetical and even grammarians treatises. Indeed, grammarians specialised in the composition of texts which analysed their specific linguistic features and composed detailed treatises which explained their properties, referring to various dialects and conventions to contextualise their actual incidence in the language of Arabic. ${ }^{12}$

The copies produced for 'Uthmān were apparently transcribed in the so-called scriptio defectiva: Arabic comprises fifteen stock graphemes or homographs. It is argued that at the time early Qur'ānic codices were written long vowels were not fully represented in the skeletal script; furthermore, diacritical dots were sparingly employed to distinguish individual characters and the script still lacked a system of short vowel annotation. The insertion of diacritic dots allowed for the phonemic replication of the 28 characters of the Arabic language. Interestingly, within the same stock of collection reports it is alleged that the omission of diacritical dots in the original 'Uthmānic codices, and even verse markers, was intentional as it is implied that such an arrangement permitted the accommodation of consonantal variants whose Qur'ānic status had been accepted. ${ }^{13}$ Archival evidence does confirm the early use of diacritics in inscriptions, although biographical literature tends to attribute the introduction of diacritics and the use of verse markers in codices with the inception of Arabic linguistic thought, a much later development, with figures such as Abū'l Aswad al-Du'alī (d. 69/689), Naṣr ibn 'Āṣim (d. 89/708), and Yaḥyā ibn Yā'mar (d. 129/746) being singled out for their enterprise in this respect; interestingly, with regards to the early use of diacritical markings it was in al-Farrā's $M a$ ' $\bar{a} n \bar{l}$ al-Qur' $\bar{a} n$ that mention is made of Zayd ibn Thābit actually making use of diacritic dots when clarifying a reading; so there is a possibility that the use of such orthographical aids did have an early provenance, although as 
This is the Accepted Version of an article published by Springer in International Journal for the Semiotics of Law - Revue internationale de Sémiotique juridique June 2016, Volume 29, Issue 2, pp 285-311. Please refer to published version when citing, available at: $10.1007 / \mathrm{s} 11196-016-9461-1$

Accepted Version downloaded from SOAS Research Online: http://eprints.soas.ac.uk/22374/

has been mentioned it is the omission of the dots which is said to have been a deliberate act on the part of the text's editors as far as a standard copy of the Qur'an sanctioned by 'Uthmān is concerned. ${ }^{14}$ Some have suggested that it is anachronistic to link such figures with innovative linguistic scholarship, although it seems reasonable to assume that as readers they engaged in activities associated with the preservation of the Qur' ān. ${ }^{15}$ Within the tradition, the existence of variances among readings is explained by the fact these were sanctioned by a Prophetic report which refers to the text of the Qur'ān being revealed in several modes or hurūf or ahruf, a term whose import was the subject of much deliberation. ${ }^{16}$ The issue of whether 'Uthmān's textus receptus encompassed these seven modes of readings, or simply one of them, was also debated with the view that it encompassed one facet of the seven hurüf becoming generally accepted among Sunni scholars. ${ }^{17}$ Shī' ite luminaries refer to its being revealed in a single harf. ${ }^{18}$ Classical scholarship was of the view that the authenticated corpus of readings derived its Qur'ānic status from Prophetic sanction and approval; later generations of readers were believed to have traced the pedigree of their readings to early luminaries. Deference to precedent was to consolidate as a key tenet in classical qira 'a $\bar{a} t$ literature with readers invoking adages such as 'al-qira $\bar{a}$ 'a sunna' (readings are defined by precedent) and ittibā' al-muṣhaf (adherence to the established codex), which operated as shibboleths of deference to the Qur'ān's linguistic and authoritative status. When the historical shifts to the standardization of readings crystallized, harmony with the 'Uthmānic codices was to become one of the defining criteria for the establishment of the Qur'annic status of a reading. While the traditional narrative accentuates the historical importance of a fixed physical text of the Qur'ān, oral mechanisms for its dissemination remained pertinent; in fact, the specialist qirā' $\bar{a} t$ biographies include synopses of the ways in which the transmission and recitation of the Qur'ān were perfected with a repertoire of technical terms used by reader experts to convey the modes of the dissemination of readings and the transfer of knowledge. ${ }^{19}$ For historians of Arabic linguistic thought, the qirā' $\bar{a} t$ provide not only insights into the synthesis of Arabic grammatical thinking during these formative periods, but they also shed light on the linguistic diversity and richness of the materials; and they can also help with the identification of the linguistic origin of materials. It has been conventional to describe readings using the term 'Qur'ānic variants', although theoretically, many of them are constellated around the standard skeletal text and proffer equally valid liturgical options for recitation. 
Variances among the documented corpus of readings tend to be confined to vocalic and homographic variants, many of which occur at the morpho-syntactic and morphophonological levels of the Qur'ānic text. They also include designated differences over the use of suffixation, prefixation and even the choice of conjunctions. A review of the classical works on collating qira' $\bar{a} t$, including early grammatical texts in which these were often analysed, such as the Kitāb al-Sab 'a of Ibn Mujāhid (d. 324/936) and al-Tadhkira fì'l-qirā' āt al-thamān compiled by Ibn Ghalbūn (d. 389/999), reveals the often very slim quality of the differences among readings; they are frequently focused on differences concerning a single phoneme or lexeme within a given verse of the Qur'ān, univocality is often a common characteristic of such simultaneous lectiones. ${ }^{20}$ In fact works such as the Kitāb al-Sab' $a$ ostensibly documented the incidence of differences (ikhtiläf) within select verses, betraying the fact that an implicit agreement existed among readers with regards to the other lexical elements of a verse (see Figure 1). It is misleading assumed that the fixing of seven readings was made inevitable through the work of Ibn Mujāhid, but in fact he was working with a prospective framework of materials and approaches to them which informed the contents of his own work and his selection of readings. There were of course collections of readings which were attributed to figures who preceded Ibn Mujāhid; indeed, in his reface he makes the telling point that he had selected readers whose readings were already wellestablished in the towns and garrison cities. ${ }^{21}$

Consonantal Variants: the use of conjunctions ((Figure I) Ibn Mujáhid's Kit bal-Sabfia
(Q. $9^{\mathbf{I} / \mathbf{I} 5)}$

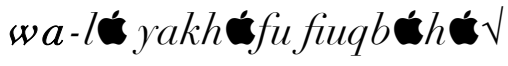
('its consequence concerns
him not')
(sourced to the skeletal text of indigenous
codices)

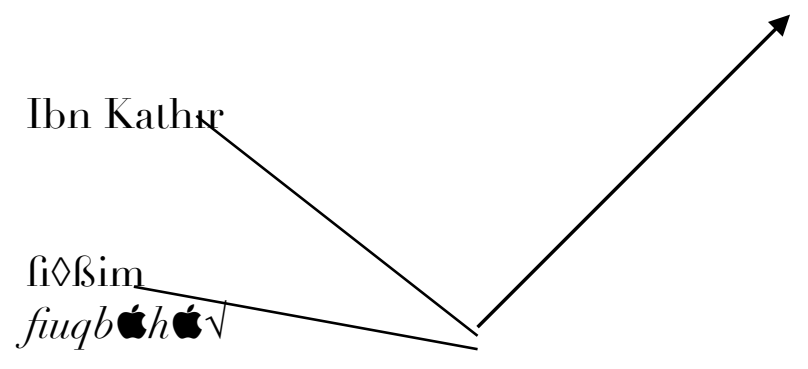

'fa-lán yak 
This is the Accepted Version of an article published by Springer in International Journal for the Semiotics of Law - Revue internationale de Sémiotique juridique June 2016, Volume 29, Issue 2, pp 285-311. Please refer to published version when citing, available at: 10.1007/s11196-016-9461-1

Accepted Version downloaded from SOAS Research Online: http://eprints.soas.ac.uk/22374/

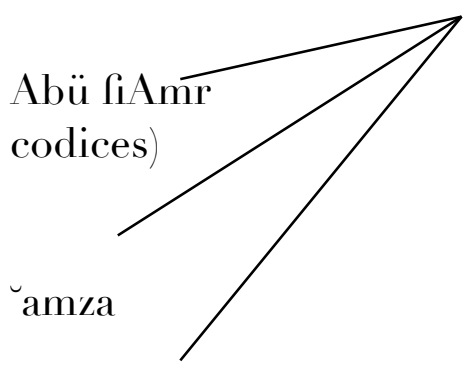

$\mathrm{Al}-\mathrm{Kis}_{\mathbf{1}} \mathrm{V}_{1}$ (sourced to the skeletal text of the Syrian and Medinan

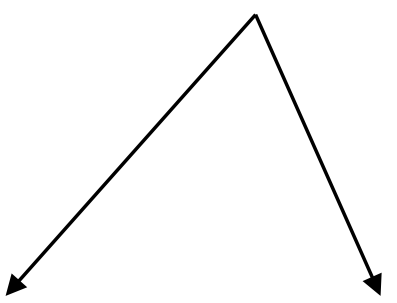

Náfífi

Ibn fißmir

Vocalic Variant:

Surat al-Burüj (Q. :I5) 'Dhü'l-fiArshi'l-Majıd(u)

'Glorious, possessor of the throne'

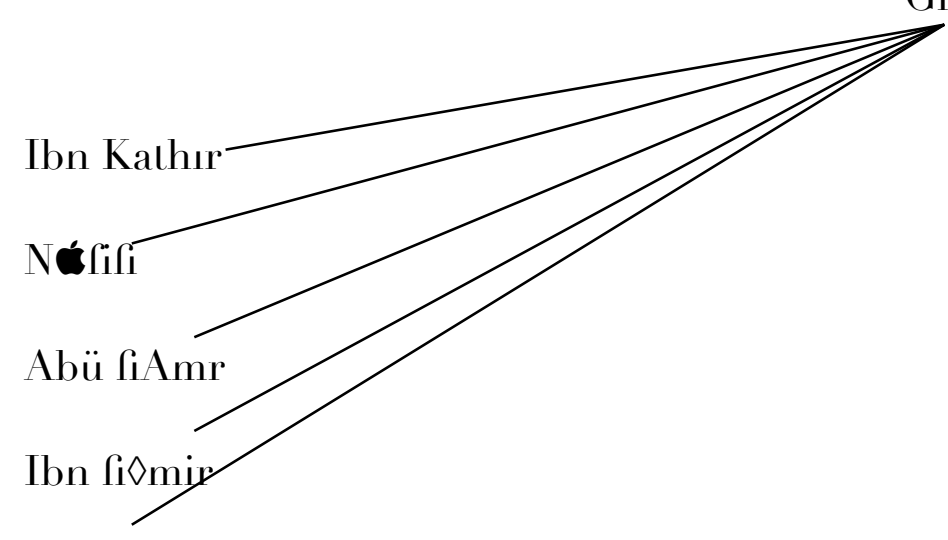

$\diamond \bowtie \operatorname{sim}$

(According to one narration)

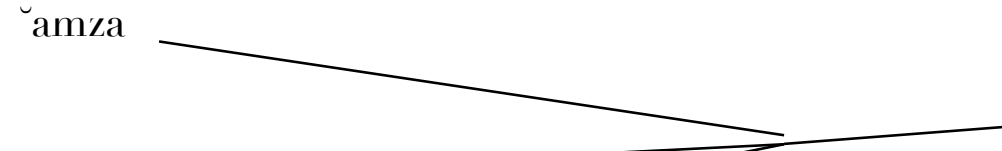

Kis ${ }^{\prime}$

fi॰ßim
Q.85/ı5) 'Dhü'l-fiArshi'l-Majid(i)'

'Possessor of the glorious throne'

(According to a second narration) 
This is the Accepted Version of an article published by Springer in International Journal for the Semiotics of Law - Revue internationale de Sémiotique juridique June 2016, Volume 29, Issue 2, pp 285-311. Please refer to published version when citing, available at: $10.1007 / \mathrm{s} 11196-016-9461-1$

Accepted Version downloaded from SOAS Research Online: http://eprints.soas.ac.uk/22374/

With reference to recitation, included in these works were discussions of topics such as idghām (phonological assimilation), kināya (the articulation of pronouns), hamz or tashīl (the omission and commission of the glottal stop), fath (opening of the vowel) imāla (fronting or inclination of the vowel) and related phonological phenomena. ${ }^{22}$

The classical literature shows that there did exist other qira ${ }^{\prime} \bar{a} t$ which exhibited sharper incidences of variance, including examples of departure from the 'Uthmānic text through exegetical interpolation, lexical and consonantal variants, and instances of the inversion of the word order (hysteron proteron) of verses; these also extended to the inclusion of vocalic variants which had no requisite documentation or apparent precedent in the qirà 'àt sources. In fact the early grammatical literature preserves fascinating anecdotes about the existence of non-standard variants and prevailing attitudes to them in the early tradition. Given in the same early sources there is an unswerving acceptance that the Qur'ān is a liturgical and devotional text, and that it was essential to ensure textual acuity on account of its being requisite to the validity of acts of worship and formal prayer, it would seem that the interest in these non-standard variants operated at an abstract level, serving exegetical, legal and even grammatical purposes as they were often being adduced to provide definition to arguments. This becomes apparent when one examines works such as the Ma'ānī al-Qur'ān texts composed by al-Farrā' (d. 207/822) and al-Akhfash al-Awsaṭ d. 215/830), and the Majāz alQur'ān authored by Abū 'Ubayda (d. 210/825). ${ }^{23}$ Such early works comprise an abundance of references to the non-standard readings ascribed to individuals such as Ibn Mas 'ūd, Ubayy ibn $\mathrm{Ka}$ 'b, and Ibn 'Abbās, yielding potential information about the historical impact of the imposition of the 'Uthmanic codex. ${ }^{24}$ For example, al-Farrā' mentions that one of the companions of 'Abd Allāh ibn Mas 'ūd, al-Ḥārith ibn Suwayd, had in his possession a codex which exhibited consonantal irregularities in relation to one specific Qur'anic verse (Q. 48:26). Al-Farrā' actually mentions his having inspected this codex in question, observing that it featured an example of hysteron proteron with the order in the verse being different from the standard 'Uthmanic codex. ${ }^{25}$ He mentioned that this specific codex was supposedly buried during the time of the Basran governor al-Hajjāj ibn Yūsuf (d. 95/714). In his Kitāb Mushkil al-Qur'ān, Ibn Qutayba (d. 276/889) reports that the readers 'Āṣim al-Jaḥdarī, Nājiya ibn Rumh and Ibn Așma' had been ordered by al-Hajjāj to shred any copy of the codex which they found contravening 'Uthmān's muṣhaf and that the owners of such codices 
This is the Accepted Version of an article published by Springer in International Journal for the Semiotics of Law - Revue internationale de Sémiotique juridique June 2016, Volume 29, Issue 2, pp 285-311. Please refer to published version when citing, available at: $10.1007 / \mathrm{s} 11196-016-9461-1$

Accepted Version downloaded from SOAS Research Online: http://eprints.soas.ac.uk/22374/

were compensated by the payment of sixty dirhams. ${ }^{26}$ Verses of poetry were even composed to commemorate the endeavours of those charged with carrying out the task.

Over subsequent historical periods, specialist readers who were linked with cities such as Mecca and Medina, and those in key garrison centres such as Kufa and Basra, developed syntheses (ikhtiyārāt) of readings which were sourced from earlier luminaries; the later qirā' $\bar{a} t$ biographical literature is structured around defining the elaborate chains of transmission for the acquisition of readings and specified the modes in which these were disseminated; with key companion figures serving as veritable founts for the readings which are linked with later readers. ${ }^{27}$ Hence for example, the Kufan reader Hamza ibn Habīb alZayyāt (d. 156/772) is said to have acquired his reading from Ḥumrān ibn A yan (d. 130/747), Ibn Abī Laylā, and A 'mash (d. 148/757), who in turn cite senior Companion figures as their authorities; even Hamza is said to have proclaimed that every single harf of his recitation of the Qur'ān was based on an authenticated precedent or athar. ${ }^{28}$ While the reader Abū 'Amr ibn al-'Alā' (d. 154/771) is recorded as having stated that if it were not for the fact that it was incumbent upon him to adhere to the precedents set by his forebears, he would have read according to his own preferences. ${ }^{29}$ The idea of adherence to precedent is also attested in the earliest surviving grammatical literature. In the Kitāb Sībawayhi discusses the 'Mā alHijāziyya', which occurs in Q.12:31, Mā hādhā bashar(an). It was viewed as being functionally analogous with Kāna, noting that the eastern Arabian tribes recited the Qur'ān verse 'Mā hādhā bashar(un)', except those aware of 'its orthography in the mușhaf'. ${ }^{30}$ The relevance of this is apparent in the opposition of sorts which developed between grammarians and readers. The former were accused of adopting an approach which was Procrustean in the sense that they criticised the validity of lectiones which supposedly contravened syntactic norms, indulging in the emendation and hypothetical projection of readings. Conversely, readers are presented as ardent defenders of precedent in the transmission and acceptance of readings. ${ }^{31}$ Certainly, later grammarians tended to devote their effort to defending and justifying the linguistic validity of readers accepted as being canonical and even those which bordered on the non-standard. In later centuries works were devoted to examining these readings with both grammatical surveys and other works which focused on the plain transmission of the materials. In such genres the hierarchy of authority for the Qur'ānic status of qir $\bar{a}$ ' $\bar{t} t$ was linked not only to their being in concordance with the 'Uthmānic codices, but also to their being theoretically traced to a Prophetic provenance and source. However, 
This is the Accepted Version of an article published by Springer in International Journal for the Semiotics of Law - Revue internationale de Sémiotique juridique June 2016, Volume 29, Issue 2, pp 285-311. Please refer to published version when citing, available at: $10.1007 / \mathrm{s} 11196-016-9461-1$

Accepted Version downloaded from SOAS Research Online: http://eprints.soas.ac.uk/22374/

history also shows there were exceptions: in the early years readers such as Ibn Muhayșin, 'Āṣim al-Jaḥdarī were reported to have adopted idiosyncratic approaches to readings: the former developed a synthesis of readings influenced by linguistic models; while, 'Āṣim is reported to have accepted the transcribed 'Uthmanic codices but been prepared to contravene the text at selected junctures on points of recitation. ${ }^{32}$ Similarly, the trials of the readers Ibn Miqsam (d. 354/965) and Ibn Shannabūdh (d. 328/939), continue to show the endurance of the spirit of grammatically inspired approaches to ikhtiyār. ${ }^{33}$

Even among certain Shī'ite movements who espoused the notion of tahrîf, the accusation that 'Uthmān and those associated with the formal collection of the Qur'ān were responsible for corrupting the text of the Qur'ān it is striking to observe that the 'Uthmānic text actually serves as the template for their readings despite polemical attempts to undermine it. This is evident in one of the earliest surviving Imāmī Shī' $\overline{1}$ literary texts devoted to qira 'a $\bar{a} t$, Muhammad al-Sayyārī's Kitāb al-Qirā'āt. ${ }^{34}$ The text includes examples of lexical substitution as well as vocalic, morpho-syntactic, and consonantal variants in addition to graphic instances of textual interpolation and glosses along. It also includes striking variations within the word order of verses. The polemical tone of the instances of textual interpolation is salient, yet when this is taken into consideration, the readings which feature in the text are unquestionably consistent with the cluster of variae lectiones permeating the works devoted to their collation and authentication within Sunnī circles. The aforementioned discussions provide a brief summary of the general thrust of the Muslim accounts on the codification of the Qur'àn as a document and the regnant significance of the 'Uthmanic codices. In the sources the reading tradition is presented as being based on the veneration of the idea that the standardized corpora of qira' $\bar{a} t$ consisted of prophetically sanctioned materials which were faithfully transmitted and preserved. ${ }^{35}$

\section{Explaining the Historical Narratives: Qirā $\bar{a} t$ in Academic Perspective}

The general reliability of the extant Islamic literary sources relevant to the collection of the Qur'àn and even the traditional accounts of the synthesis of qirā' $\bar{a} t$ tends to be treated with guarded caution in current academic scholarship. These accounts are viewed as exemplifying a subjective attempt to present an idealised view of the Qur'ān's formation as a text, glossing 
This is the Accepted Version of an article published by Springer in International Journal for the Semiotics of Law - Revue internationale de Sémiotique juridique June 2016, Volume 29, Issue 2, pp 285-311. Please refer to published version when citing, available at: $10.1007 / \mathrm{s} 11196-016-9461-1$

Accepted Version downloaded from SOAS Research Online: http://eprints.soas.ac.uk/22374/

over the historical details of the actual processes which led to the standardisation of the text. The paucity of independent records in the form of supporting manuscript, numismatic and archaeological evidence is also flagged to support the need for discretion when relying on later narratives. Thus, while the traditional sources proffer a confident account of the ways the text was standardised and preserved, intimating this was achieved with remarkable acuity, it is claimed that not only are there discrepancies in the accounts, but also that the extant manuscript tradition, which is admittedly fragmentary, does not tally fully with the history preserved in the Muslim tradition. It was these concerns which were foremost in the work of John Wansbrough who sought to explain the formation of the Qur'ān as a literary text through reference to a typological synthesis of the literary genres used to contextualise the Qur'ān; subtle shifts in the language and content of these genres suggested to Wansbrough that they did not presuppose the existence of a canonical text of the Qur'ān, but rather they were delicately designed to fortify the perception of there existing a fixed text. Referring to the work of scholars such as Gotthelf Bergsträsser, Otto Pretzl, and Arthur Jeffery, Wansbrough argued that the non-canonical (amșār) codices did not display the 'differences either among themselves or from the 'Uthmānic recension which are alleged to have provoked the editorial measures attributed to the third caliph' and that even the welter of noncanonical variants which are attributed in the source materials to Ibn Mas 'ùd did not appear to be 'not genuinely independent of the 'Uthmānic recension'. ${ }^{36} \mathrm{He}$ posited that the chronological sequence of literature on the Qur'ān does not presuppose 'a standard or ne varietur text as early as the middle of the first/seventh century', adding that infinitesimal differences are not such as would seem to have necessitated a suppression of the non'Uthmānic versions, the more so since a minimal standard deviation from the canon was accommodated by the interpretation of the ahruf doctrine'. He concluded that 'either the suppression of non-standard deviations was so instantly and universally successful that no trace of serious opposition remained, or that the story was a fiction designed to serve another purpose'. He identified variant readings as belonging to elements of 'masoretic' exegesis, which according to his typology, had a much later historical provenance. However, subsequent manuscript discoveries critically undermined his thesis with regards to the issue of origins. Scholars who focus exclusively on the study of the earliest fragments of manuscript evidence also appear cautious with regards to the reliability of traditional accounts of the history of the text. 
This is the Accepted Version of an article published by Springer in International Journal for the Semiotics of Law - Revue internationale de Sémiotique juridique June 2016, Volume 29, Issue 2, pp 285-311. Please refer to published version when citing, available at: $10.1007 / \mathrm{s} 11196-016-9461-1$

Accepted Version downloaded from SOAS Research Online: http://eprints.soas.ac.uk/22374/

François Déroche has concluded that although there is 'the possibility that some of the fragments date back to the decade that elapsed between the murder of 'Uthmān (35/656) - or even before - and the beginning of Umayyad rule can in no way be excluded, but we do not have strong arguments - material or textual - to attribute precisely to this period any of the manuscripts or fragments which are currently known to us' ${ }^{37} \mathrm{He}$ counsels that the dating of the earliest fragments remains a speculative exercise, albeit observing that through a combination of disciplinary approaches, including areas such as palaeography, philology, art history and the analysis of Carbon 14 dating, it is "possible to state that we do have more or less substantial parts of copies which can be dated to the Umayyad period', but that 'there is for the moment little which can be argued in support of a very early date'. ${ }^{38}$ Scholars do have reservations about the C-14 dating of Qur'ānic fragments as the recent claims over the Birmingham manuscript (ms 1572) show. Déroche takes the view that striking changes to the codification of the text were delivered under the Umayyads who instigated the production of Qur' ānic manuscripts of the highest quality, although he speaks of there being 'no certainty that the qira 'a $\bar{a} t$ of the Umayyad period were similar to those which we know'. ${ }^{39}$ With regards to the San ' $\bar{a}$ ' palimpsest, the study of Sadeghi and Goudarzi does posit an early date for its scriptio inferior (the under text), underlining its non-standard format. While, at the same time, alluding to the 'fairly effective' attempts by 'Uthmān to standardise the text, they argue that the suras that formed the text were shaped earlier. ${ }^{40}$ Déroche, also referring to Sadeghi and Goudarzi, and questioning the need for caution when relying upon $\mathrm{C} 14$, suggests that the scriptio inferior was 'written during the second half of the first seventh century'. ${ }^{41}$ Work on the study of early Qur'ānic manuscripts is still in its early stages. $^{42}$

While Wansbrough questioned the historical status and function of the corpus of qira 'a $\bar{t}$ and linked their genesis to the attempts to project the notion of a fixed canon, it was John Burton who argued that specific types of variant readings were the contrived products of delicate attempts to pursue legal arguments, countering not only legal inconsistencies in the text of the Qur'ān and the Prophetic sunna. He devoted a monograph to explaining the formation of early legal thinking and its ideological basis through reference to the collection of the Qur'ān. Building upon the conceptual foundations of the arguments of both Ignaz Goldziher and Joseph Schacht, he questioned the origin of specific types of variae lectiones. He was particularly interested in the role played by ușul al-fiqh in fashioning the history of 
This is the Accepted Version of an article published by Springer in International Journal for the Semiotics of Law - Revue internationale de Sémiotique juridique June 2016, Volume 29, Issue 2, pp 285-311. Please refer to published version when citing, available at: $10.1007 / \mathrm{s} 11196-016-9461-1$

Accepted Version downloaded from SOAS Research Online: http://eprints.soas.ac.uk/22374/

the collection of the Qur'ān texts and he identified a selection of latent ideological imperatives which he argued were driving legal discussions. His thesis was that specific types of variae lectiones were not relics of a corpus transmitted with textual fidelity over extended historical periods, but engendered by a labyrinth of legal arguments whereby the wording of the sacred text, in this instance the lectio, was interpolated or altered vocalically in order to lend support to perspectives supported by provincial schools of law. ${ }^{43}$ Schacht had attributed the formulation and dissemination of legal teachings to the indigenous fiqh schools, dismissing the view that teachings and practices had their origin in the Medinan milieu. In the words of Burton, Schacht had shown that 'reference of the Sunna to the Prophet was the end rather than the beginning of a process', and that 'the hadith conveys a truth that is theoretical rather than historical'. ${ }^{44}$ Burton concluded that the reports of the collection of the Qur'an represent 'a mass of confusions, contradictions, and inconsistencies', and were the produce of a 'lengthy process of evolution'. ${ }^{45} \mathrm{He}$ inferred that Qur'ānic manuscripts exhibit the 'Uthmānic text and if one were to remove the collection reports as 'never having occurred', one arrives at the conclusion that the recension of the Qur'ān was the work of the Prophet [25, p. 227]. Ideological imperatives led to the attempt to place distance between the Prophet and the collection of the codices. Separately, Harald Motzki argued that specific traditions about the collection of the Qur'ān were put in circulation by the traditionist Ibn Shihāb al-Zuhrī (d. $124 / 741$ ), reckoning that they appeared in the first quarter of the second century, although, his view is also that such materials could hypothetically have been acquired from earlier informants. $^{46}$

More recently, Shady Nasser posited a legal nexus to the proliferation of readings, arguing that they continued to multiply exponentially until the time Ibn Mujāhid authored his seminal Kitāb al-Sab'a. However, Nasser is not specifically concerned with the legal significance of the variant readings, but rather his supposition is that readings were freely amalgamated and synthesised by reader specialists in ways which mirrored conventions

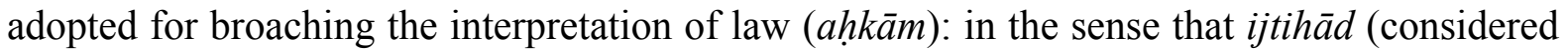
opinion) and ikhtiyār (personal preference) were key elements which guided the processes of authentication and selection. Interestingly, Nasser reckoned even esteemed figures such as alTabarī (d. 310/923) never considered 'variants' to be sanctified or the product of divine revelation. ${ }^{47}$ 
This is the Accepted Version of an article published by Springer in International Journal for the Semiotics of Law - Revue internationale de Sémiotique juridique June 2016, Volume 29, Issue 2, pp 285-311. Please refer to published version when citing, available at: $10.1007 / \mathrm{s} 11196-016-9461-1$

Accepted Version downloaded from SOAS Research Online: http://eprints.soas.ac.uk/22374/

\section{Qira $\bar{a} \bar{t}$ and Legal Discourses: Gauging the Corpora}

Attitudes to readings within the early classical literature have been the subject of numerous studies, yet the idea that specific types of readings were generated through early legal discourses has not been fully probed, particularly in terms of shedding some light on the role that differences among concomitant readings played in the synthesis and interpretation of law in classical discourses. The infrequency with which the attestation of concomitant variants appears in classical legal disputations suggests that their influence upon such discussions remained somewhat peripheral. This is evident when one takes into account not only the sheer volume and range of the corpora of qira ' $\bar{a} t$, but also the scale and diversity of classical juridical thought. It was certainly the case that the issue of the classification of readings did feature in $\bar{u} s \bar{u} l$ al-figh discussions within the context of defining canon and the related issue of attitudes to those materials designated as being isolate (shädhdha or shawādh) with regards to acts of worship and their attestation as sources of law. However, the sample of Qur'ānic verses in which concomitant variant qira $\bar{a}^{\prime} \bar{t}$ connected with a single verse lead to conflicting legal rulings remains relatively confined, although this in no way diminishes the intrinsic sophistication and resourcefulness which mark the instances in which they are employed in such discussions.

\section{al-Ṣafā wa'l-Marwā: the Question of the Mandatory Status of tawāf,}

The ritual rite of performing circuits ( a $^{\prime} \bar{l}$ or țawăf) between the two hills of al-Șafā wa'lMarwā, which are annexed to the Meccan sanctuary, yields a prominent instance in which the attestation of concomitant variants featured prominently in classical legal debates about the requisite nature of the circuits. The Qur'ān states in Q. 2:158 that: 'Indeed Safa and Marwa are among the rites of God and whoever performs the pilgrimage or partakes in a lesser visit, then there is no harm in their circulating between the two (hills); and whoever volunteers then that is good for them; be aware that God is benevolent and all knowing.' In the traditional literature the significance of the practice of performing circuits between these landmarks is pored over at length. According to one tradition, the Companion Anas ibn Mālik (d. c. 93/710-11) was asked about the status of al-Șafā wa'l-Marwā and he recounted that in the 
This is the Accepted Version of an article published by Springer in International Journal for the Semiotics of Law - Revue internationale de Sémiotique juridique June 2016, Volume 29, Issue 2, pp 285-311. Please refer to published version when citing, available at: $10.1007 / \mathrm{s} 11196-016-9461-1$

Accepted Version downloaded from SOAS Research Online: http://eprints.soas.ac.uk/22374/

pre-Islamic period these landmarks were ignominiously associated with idolatrous customs to the extent that with the emergence of Islam, Muslims refrained from circuiting between them, following which Q. 2:158 was revealed, encouraging pilgrims to circuit between the two landmarks. ${ }^{48}$ Other connected hadīth also refer to the sites al-Ṣafā wa'l-Marwā being connected with polytheistic practices and customs which apparently led to their being shunned by the community with members of the Anșār stating that they were only commanded to circumambulate the Ka'ba. The discussions about the tawāf appear to have been contentious: in a related tradition the wife of the Prophet ' $\overline{\mathrm{A}}$ ' isha is informed by her nephew 'Urwa ibn al-Zubayr that he saw no ritual detriment or deficit if one were to omit circuiting between these two landmarks; he is reported to have assertively exclaimed that 'circuiting between them matters not to me'. ${ }^{49}$ According to the same tradition, ' $\bar{A}$ 'isha, startled by her nephew's views, responded by saying: 'What a shocking statement you have uttered! The Prophet and the Muslims performed circuits between them. It was the practice of those who entered into a consecrated state by invoking the goddess al-Manāt to refrain from performing circuits between al-Ṣafā wa'l-Marwā and this occasioned God's revelation of the verse'. She then stated that had its omission been permissible, the verse would have read " $f a$ lā junāha 'alayhi 'an (lā) ya'țawwafa bihimā (there is no harm in your not performing circuits between these two landmarks) which could have been adduced to support its omission from the pilgrimage rites. There does exist a variant reading and wording of the verse attributed to both Ibn Mas' $\mathrm{u} d$ and Ubayy ibn Ka'b which explicitly includes in it the additional 'an la ya'ttawwafa bihima (elided to allā). The reading breaches the skeletal text of the 'Uthmānic codex.

The verse is briefly discussed in al-Farrā's $M a$ ' 'ān $\bar{\imath}$ where it is also explained that the performance of circuits between these landmarks was shunned by Muslims because of two idols placed on them, fearing that their circuiting between the two landmarks could be misconstrued as an act of veneration for these idols. Still, having provided an explanation which fits in with the conventionally accepted narrative which encourages circuits between the landmarks, al-Farrā' does include an allusion to the variant in which the reading ' $a n$ (lā) ya 'țawwafa bihimà' 'is mentioned. He does not ascribe the reading to Ibn Mas' $\bar{u} d$ nor indeed Ubayy, but focuses on clarifying the reading: firstly, he explains that the combined an $(l \bar{a})$ particle exhibits an example of "șila" (superfluity), namely, linguistic redundancy and connotes fa-lā junāḥa 'alayhi 'an ya'țtawwafa bihimā. Having spoken about the 
This is the Accepted Version of an article published by Springer in International Journal for the Semiotics of Law - Revue internationale de Sémiotique juridique June 2016, Volume 29, Issue 2, pp 285-311. Please refer to published version when citing, available at: $10.1007 / \mathrm{s} 11196-016-9461-1$

Accepted Version downloaded from SOAS Research Online: http://eprints.soas.ac.uk/22374/

grammatically otiose function of the elided particle, he then adduces a second verse which has analogous structural elements to support that perspective: Q. 7:12, which reads ' $m \bar{a}$ mana 'aka 'an (lā) tasjud idh amartuk ('What prevented you from falling prostrate in the wake of my command'. ${ }^{50}$ Al-Farrā' then switches his attention to the second explanation which he observes allows the concession of omitting the circuits between these landmarks, adding that the first explanation is the one which is upheld. It is arresting that in al-Farrâ's discussions is that there is no attempt to accentuate the significance of the variant reading which could be adduced to support omitting the circuits; in fact, he provides a grammatical explanation which dissipates the relevance of the reading. Moreover, in al-Farrā' 's treatment the connected lectio is alluded to very cursorily and deemed almost inconsequential within the body of his discussions, despite the fact that the reading was connected with the Kufan legacy of Ibn Mas' $\bar{u} d$.

The same verse is subjected to a lengthy examination in al-Țabarī's Jāmi 'al-bayān 'an ta'wīl ây al-Qur'ān. ${ }^{51}$ In this, initially, the ritual relevance of performing the circuits between these landmarks is linked with the legacy of Abraham and the discussions include a methodical review of the various philological and poetic citations germane to the content of the verse. However, later on within his analysis, al-Tabarī does bring up a possible query raised with regards to the overall semantic thrust of the verse which is posed in the form of a dialectical question. He states that the former part of the verse declares that 'al-Șafā and Marwā are among the sacred rites of God', he then explains that subsequently within the verse it is proclaimed that 'there is no harm in their circulating between the two landmarks', asking how can the former part of the verse supposedly be understood to make it an obligation to circuit between the landmarks, when the latter part speaks of there being 'no harm' in omitting the circuits, suggesting a disjunction of sorts as the lexeme junāh is equated with impairment and sin: it would be illogical to talk about an obligation, but then link it to there being no sin associated with its performance. Dismissing such an interpretation, al-Ṭabarī reports that the verse has to be grasped within the context of the preIslamic narrative which has idol worship associated with the landmarks and the discussions incorporate the various dicta attributed to the pious ancestors concerning the circuits at alȘafā wa'l-Marwā being linked with this. He argues that when this background is taken into account, the wording of the verse makes sense. A plethora of reports is adduced to support that explanation, including the dictum attributed to 'A $i$ 'sha in which she insists that the 
This is the Accepted Version of an article published by Springer in International Journal for the Semiotics of Law - Revue internationale de Sémiotique juridique June 2016, Volume 29, Issue 2, pp 285-311. Please refer to published version when citing, available at: $10.1007 / \mathrm{s} 11196-016-9461-1$

Accepted Version downloaded from SOAS Research Online: http://eprints.soas.ac.uk/22374/

circuits were mandatory and her referring to the 'hypothetical' reading which would be required to substantiate their omission.

Al-Ṭabarī includes a report which mentions that certain tribes from Tihāma used to omit the circuits between these landmarks, which prompted the occasion of the revelation of the verse. He then offers his own summary of the reports stating that it was not possible to infer on the basis of the verse that prior to its revelation there was some sort of divine prohibition on performing the circuits which was then rescinded. Al-Tabarī then outlines the various positions taken by jurists regarding the ritual status and validity of these circuits. He recounts that some jurists equated missing the circuits between al-Ṣafā wa'l-Marwā with omitting the mandatory circumambulation of the Ka' $\mathrm{ba}$, ruling that this would invalidate the ritual integrity of the Hajj: pilgrims would need to return to Mecca and perform the circuits otherwise their pilgrimage would be voided. There were also further views, one of which refers to an expiatory sacrifice being necessary in lieu of a pilgrim's having to return to Mecca to perform the circuits; while, an additional view simply designated the circuits between these landmarks as being purely voluntary. The requisite proofs adduced by various proponents of these views are then listed. Thus, al-Shāfî́ $1 \overline{1}$ is noted for insisting that a pilgrim should return to perform the sa ‘̄; Abū Hanifa (d. 150/767), Abū Yūsuf (d. 182/798), and Muhammad al-Shaybānī (d. 189/804) are associated with the opinion that expiation alone suffices; and finally, the variant reading of Q. 2.158 is mentioned in a report citing a discussion between Ibn Jurayj (d. 150/767), and 'Ațā' ibn Abī Rabāḥ (d. c. 114-5/732-733), who professes the opinion that the omission of circuits between these landmarks does not invalidate the Hajj, due to their being a voluntary act which is based on the lectio preserved in the mușhāf of Ibn Mas'ūd (fa-lā junāha 'alayhi allā ya'țtawwafa bihimā). When Ibn Jurayj remonstrated by saying that such a person has 'discarded the practice of the Prophet', 'Ațầ' responded by reciting the succeeding verse: 'whoever volunteers, then that is good for them', intimating that it was a complement to the same verse, although whether this segment in the verse is connected with the previous discussions is a moot point. ${ }^{52}$ Other figures who likewise endorse the view, citing the codex of Ibn Mas ' $\overline{\mathrm{u}}$, are mentioned by al-Ṭabarī and these include the Companions Anas ibn Mālik and 'Abd Allāh ibn al-Zubayr, together with the exegete Mujāhid (d. 104/722), all of whom regarded these circuits to be strictly voluntary and non-binding: its omission did not impinge upon the validity of the performance of an individual's hajj. 
This is the Accepted Version of an article published by Springer in International Journal for the Semiotics of Law - Revue internationale de Sémiotique juridique June 2016, Volume 29, Issue 2, pp 285-311. Please refer to published version when citing, available at: $10.1007 / \mathrm{s} 11196-016-9461-1$

Accepted Version downloaded from SOAS Research Online: http://eprints.soas.ac.uk/22374/

Subsequently, al-Tabarī then offers his own musings in which he states categorically that the tawa $\bar{f}$ between these landmarks is both obligatory and necessary, explaining that if one were to omit the circuits, deliberately or unintentionally, then that individual would need to return to Mecca to complete them. He even refers his reader to his own composition on the principles of jurisprudence (al-Bayān 'an uṣul al-aḥkām), and his having set out in it the importance of the hierarchical authority of Prophetic precedent and the general consensus of scholars on such points, reiterating that the practice of tawa $f$ between these landmarks was sanctioned by the Prophet. It was his contention that neither ransom nor expiation could compensate for its omission and that a pilgrim would have to return to Mecca to perform the circuits. Al-Tabarī too draws an equivalence between these circuits and the circumambulation of the Ka'ba: someone omitting the mandatory tawāf of the Ka'ba would have to return to complete them. It is at this juncture that al-Ṭabarī alludes to objections that might be raised by those who adduce the concomitant reading of the verse attributed to Ibn Mas 'ūd. His response is unequivocally strident: he insists that the reading in question egregiously contravenes the accepted codices (mașāhif al-Musliminn), emphasising that it was not permissible for anyone to augment the skeletal text of the codex with something superfluous in this or any other instances. ${ }^{53}$ He perceives that such a person would deserve reprimand. At the end of his disquisition, al-Tabarī replicates the analysis provided by al-Farrā', commenting on the linguistic redundancy of the elided alla particle, which attenuates the legal efficacy of Ibn al-Mas 'ūd's reading as an argument for omitting the tawāf: for in his words, even if the rasm of the mușhaf accommodated such a reading, it could not be used as the basis for substantiating the view that circuits between the landmarks of al-Șafā wa'lMarwā were entirely optional. Notably, while Ibn Mas 'ūd's reading was used by scholars who were keen to defend the optional status of the tawa $f$, it featured alongside the attestation of other dicta as part of an entwined panoply of arguments invoked to influence discussions. One does not form the impression that differences over the lectio critically determined the dynamics of the arguments. And it remains debatable whether the reading was the product of a critical attempt to counter an alterative practice, but it appears as one among a selection of dicta used to formulate and contextualise legal discussions.

In later legal discussions one does find jurists discussing the issue of the mandatory status of the tawa f ( $a^{(} \vec{\imath}$ ), although, again, the bearing of the reading upon the various arguments appears marginal: for example, Ibn Qudāma notes that different views were 
This is the Accepted Version of an article published by Springer in International Journal for the Semiotics of Law - Revue internationale de Sémiotique juridique June 2016, Volume 29, Issue 2, pp 285-311. Please refer to published version when citing, available at: $10.1007 / \mathrm{s} 11196-016-9461-1$

Accepted Version downloaded from SOAS Research Online: http://eprints.soas.ac.uk/22374/

attributed to Ibn Hanbal (d. 241/855) on this matter: in one narration he is reported to have designated the $s a \mathfrak{\imath}$ as being an essential element of the hajj; however, he was also associated with a second view in which he stated that one's omitting these rites would not necessarily trigger an expiatory sacrifice, but this view was inferred from the part of the verse which states 'there is no harm in their circulating between the two (hills)', which implied that it was not obligatory but fell within the realm of permitted acts. With regards to Ibn Hanbal, no mention is made of the reading which is in fact cited as part of Ibn Qudāma's gloss where he states: 'It is reported that the muṣhafs of Ubayy and Ibn Mas' ūd read: fa-lā junăhā 'alayhi allā ya'tțawafa bihimāa. Ibn Qudāma then remarks that 'even if this is not Qur'ānic, it still has the weight of a form of narration (khabar) and has no less authority as such'. ${ }^{54}$ So, the legal strength of appealing to these variants is by no means pivotal to the discussions on the tawa $f$, but part of an integrated set of arguments. Attitudes of the schools of jurisprudence to the status of so-called isolate readings (qirā'āt shädhdha) did vary. The Hanbali jurist alMardāwī (d. 885/1480) provides a useful summary of the positions in his legal commentary al-Tahbirr, making it clear that the recitation of materials designated as being shädhdha in acts of worship was disliked, although, there did exist dissenting views. ${ }^{55}$ The gamut of perspectives on the subject is summarised by Ibn al-Jazarī (d. 833/1429) in his Kitāb alNashr, although one needs to bear in mind that he was often passing judgement on debates which originated in later periods. ${ }^{56}$ With regards to their use in legal arguments, most Hanafite scholars argued that the shädhdha readings constituted a proof (hujja) ${ }^{57}$ It appears as one of two positions taken by Ahmad ibn Hanbal, particularly in cases where such readings are adduced preponderantly to consolidate an argument. These views are alluded to in Ibn Qudāma's Rawdat al-Nāzir. ${ }^{58}$ In opposition to this view is the Mālikite position which rejects their hujja status and utilization ${ }^{59}$; Ibn Hazm (d. 456/1064) was also critical of their use for the purposes of citation. ${ }^{60}$ Among the Shāfi ites, Sayf al-Dīn al-Āmidī (d. 630/1233) and al-Nawawī (d. 767/1277) are reported to have insisted on their non-hujja status, implying that this was the position of the school's eponym. Al-Isnawi (d. 772/1370) rejects this, stating that the Muhktașar of al-Buwayțî confirms that the contrary was true. ${ }^{61}$

Separately, one does need to bear in mind that the semantic compass of the term shādhdha appears to have evolved considerably. Among the works attributed to Ibn Mujāhid in the Fihrist are the Kitāb al-Qirā' 'ät al-șaghīr and the Kitāb al-Qirā'āt al-kabīr. In his Kitāb al-Muhtasab Ibn Jinn̄̄ explains that during Ibn Mujāhid's era readings were divided 
This is the Accepted Version of an article published by Springer in International Journal for the Semiotics of Law - Revue internationale de Sémiotique juridique June 2016, Volume 29, Issue 2, pp 285-311. Please refer to published version when citing, available at: $10.1007 / \mathrm{s} 11196-016-9461-1$

Accepted Version downloaded from SOAS Research Online: http://eprints.soas.ac.uk/22374/

into two broad categories: readings concerning which there existed a common consensus among the principal readers as to their established status and it was this body of material that he collated in his Kitāb al-Sab 'a. ${ }^{62}$ He then points out that the so-called shädhdha materials which fell outside the compass of the seven were also divided into two categories: those which were genuinely aberrant and did not warrant attention; and, those which did deserve consideration due to their retaining notable merits in terms of their linguistic qualities and paths of transmission, explaining that he was emulating the methodology of Ibn Mujāhid who had also composed a work devoted to these types of shädhdha materials. The implication is that of the two categories of shädhdha materials, the latter were not to be considered disdained; they simply did not enjoy the levels of transmission enjoyed by the corpora associated with the seven readings. However, over subsequent centuries, all these materials were being defined in light of the debates about the notions of tawätur, which were associated with multiple numerical transmission, despite their being initially connected with the construct of broad consensus and universal acceptance. ${ }^{63}$

It was Burton who argued that the existence of the Ibn Mas' $\overline{\mathrm{u}}$ and Ubayy readings provided evidence of the structural traces of the historical layers to the arguments developed to defend legal doctrines among opposing jurists in the early Islamic tradition. His supposition was that it was an example of an attempt to situate 'fiqh views under the aegis of the Qur'ān' by proffering changes to the text of the Qur'ān and was linked to the opposition between locally derived jurisprudence. ${ }^{64}$ In this sense it was redolent of the discourse of legal disputation. Burton's suspicions were further aroused by the conspicuous fact that the reading attributed to Ibn Mas 'ūd was expediently proposed by ' $\overline{\mathrm{A}}$ ' isha, albeit hypothetically, in a separate dictum. Ex hypothesi, Burton insisted that the 'so-called Companion codices could only have been posterior, not prior, to the 'Uthmānic text'. He believed that the appeal to these codices was part of adeptly developed legal and exegetical stratagems. ${ }^{65}$ It should be stated that if this were the case, within the context of legal debates and arguments, one would have expected a much greater corpus of concomitant readings with legal implications to have been in circulation.

Conflict and the Imposition of Capital Penalties within the Vicinity of the Meccan Sanctuary 
This is the Accepted Version of an article published by Springer in International Journal for the Semiotics of Law - Revue internationale de Sémiotique juridique June 2016, Volume 29, Issue 2, pp 285-311. Please refer to published version when citing, available at: $10.1007 / \mathrm{s} 11196-016-9461-1$

Accepted Version downloaded from SOAS Research Online: http://eprints.soas.ac.uk/22374/

While the aforementioned Ibn Mas'ūd reading provided an instance of a lectio which conflicted with the standardised codices, even though grammarians were able to explain away its legal efficacy by referring to the linguistic redundancy of the alla particle, discussions concerning segments from Q. 2: 191 were based on concomitant vocalic variants which were accommodated within the 'Uthmānic text. The latter half of the verse is germane to the issue of conflict within the vicinity of the sacred sanctuary, part of which states: 'Do not fight them in the vicinity of the sanctuary unless they engage with you there; and if they do fight with you (there), then fight them'. There are two traditionally authenticated variants of the readings, the first of which reads (wa-lā tuqātilūhum 'inda al-Masjidi'l-Harāmi hatāa yuqātilükum fihi; fa'in qätalükum, fa'qtulühum'), in which the verb qatala appears in the 3rd form (qātala); while, the second reading retains the base form of the verb which is recited: wa-lā taqtulūhum 'ind al-masjid al-ḥarām hatā yaqtulūkum fihi; fa'in qatalükum, fa'qtulūhum'. Ibn Mujāhid points out that readers differed concerning the verse over 'whether the alif (of the verb) should be included or omitted', noting that throughout the verse, Ibn Kathīr (d. 120/738), Nafi' (d. 169/785), 'Āṣim (d. 127/744), Abū 'Amr, and Ibn 'Âmir (d. 118/736) read the 'qatala' verb with the alif ( $3^{\text {rd }}$ form); though, Hamza (d. 156/772) and al-Kisầ' (d.189/804), read without the alif throughout the verse. He mentions that the segment containing the apodosis (fa'qtulühum) was read by them all without an alif. ${ }^{66}$ Separately, the legal differences over the import of the verse in general are disputed with regards to the issue of waging war and conflict; indeed, the argument as to whether the verse was abrogated or concurrently binding was pored over in the attendant literature. Still, notwithstanding the relevance of these more broad discussions, the concomitant readings based on the choice of verb forms feature in the legal deliberations, although it was the sundry Prophetic dicta which carried greater cachet within the concatenation of perspectives adduced in the discussions.

The significance of the two readings rests on the shrewd employment of a simple $a$ fortiori argument: if on the basis of the reading with the alif the Qur'ān prohibits 'fighting' in the vicinity of the sanctuary, then it immediately follows that the taking of a life within the precincts of the mosque, which is graver than simply engaging in combat, is much more reprehensible and therefore illicit. It was in this context that jurists cited the semantic nuances between the two readings to reach judgments not only about engaging in warfare, but also whether it was permissible to take the life of an individual who sought sanctuary in the 
This is the Accepted Version of an article published by Springer in International Journal for the Semiotics of Law - Revue internationale de Sémiotique juridique June 2016, Volume 29, Issue 2, pp 285-311. Please refer to published version when citing, available at: $10.1007 / \mathrm{s} 11196-016-9461-1$

Accepted Version downloaded from SOAS Research Online: http://eprints.soas.ac.uk/22374/

Meccan shrine and whether corporeal offences should be imposed within it boundaries. ${ }^{67}$ There is no suggestion that there is an antithesis as far as the semantic import of the two readings is concerned. In his Aḥkām al-Qur'ān the jurist Ibn al-'Arabī (d. 543/1148) relates an anecdote relating to the celebrated jurist al-Ṣāghānī who was questioned about the permissibility of taking the life of an adversary who had sought sanctuary within the Meccan shrine. His response is that the two readings respectively predicate that initiating combat without provocation in the sanctuary was prohibited and that it could be inferred from the verse that the taking of a life within the precincts of the Masjid al-Harām was forbidden; in the case of the tuquatilühum reading the ruling is presented by way of caution (tanbīh) and it is here that the a fortiori argument is applicable, while in the second, taqtulühum, prohibition is textually stipulated as being clear cut (nașs) and categorical. ${ }^{68}$ Neither the Qur'ānic verses nor the relationship between the concomitant readings actually impinges upon the rest of the discussions, but rather debates about whether the verse was abrogated by virtue of a second Qur'ānic revelation are key: namely, the verse which states 'Whoever enters it enjoys protection' (Q. 3: 97). Abū Hanifa and Ibn Hanbal are reported to have espoused the view that it was not permissible to implement penal laws in the confines of the Meccan sanctuary; while, al-Shāfi' $1 \overline{1}$ and Mālik argued that there were additional Prophetic dicta which could be cited as evidence for their implementation in the sanctuary. ${ }^{69}$ Clearly, the differences between the two readings are not the source of any disputes or disagreement as far as the legal import of the verse is concerned: the linguistic nuances furnished by the concomitant readings are simply conscripted into the general discussions, forming part of a broadly integrated corpus of dicta used to give definition to the debates.

This is likewise true for Q. 2:125, which refers to the adoption of the location where Abraham prayed in the Meccan sanctuary as a place of prayer. The verb in the verse can be read either as an imperative command or, as a verb in the past tense. This is also the case for the references to reconciliation in divorce (Q. 2: 229). And even the lectio on exemptions with regards to fasting attributed to Ibn 'Abbās in which the $w \bar{a} w$ replaces the $y \bar{a}$ ' in $(\mathrm{Q}$. 2:184), read as (yutawwaqūnahu), the differences in question do not lead to an opposition between legal rulings. ${ }^{70}$

\section{Rules Pertaining to Ablution and Ritual Purity}


This is the Accepted Version of an article published by Springer in International Journal for the Semiotics of Law - Revue internationale de Sémiotique juridique June 2016, Volume 29, Issue 2, pp 285-311. Please refer to published version when citing, available at: $10.1007 / \mathrm{s} 11196-016-9461-1$

Accepted Version downloaded from SOAS Research Online: http://eprints.soas.ac.uk/22374/

The marginality of the impact that differences between concomitant readings had upon the unfolding of legal discussions, especially when cited within the context of a single verse, can be observed in the Qur'ānic injunction which deals with reference to ablution, ritual washing and concessions for travellers. The Qur'ān states (Q. 4:43) 'Oh you who believe do not approach prayers if you are intoxicated until you are mindful of what you utter; nor (approach prayers) if you are in a state of being ritually impure, unless you are passing through the area of prayer, until you have cleansed yourself. Additionally, if you are unwell, engaged in travel, or have relieved yourself; and too, if you have had intercourse (lämastum) with your women, but are unable to find water, then seek out soil that is unpolluted and wipe your faces and hands with it; indeed God is lenient and forgiving' (Q. 4:43). There do exist two readings of the verse: Ibn Mujāhid notes that Ibn Kathīr, Nāfi' ' 'Āṣim, Abū 'Amr and Ibn 'Āmir all read the verse in the $3^{\text {rd }}$ form, including an alif; while, the Kufans, Hamza and al-Kisā' $\overline{1}$, read the verse in its stem form, lamastum. ${ }^{71}$ The debates among scholars on the subject of instances where ablution was required are not configured around the readings of this verse but form elements of a wider discussion concerning the nature of physical contact between a man and his female partner, with the different interpretations and citation of Prophetic dicta inexorably driving the deliberations. Most commentators argued that both Qur'ānic readings (lämastum/lamastum) imply sexual contact and the nuances between them were tangential to the arguments developed around the issue. In Ibn Qudāma's Kitāb al-Mughnī the related implications of the subject are dealt with under the heading 'Physical Contact between a Man and Woman with Sexual Intent', where the author remarks that different opinions on this subject were ascribed to Ibn Hanbal. ${ }^{72}$ In a certain narration he is reported to have stated that in instances of physical contact, the ritual ablution of a man would be invalidated only if there is sexual intent during contact; and Ibn Qudāma specifies that this was a view shared by a number of distinguished jurists. It is correspondingly noted that these scholars stated that ritual ablution would not be invalidated if one were to kiss (qabbala/qubla) one's partner, with the intention of displaying 'kindness' or 'compassion'. Other jurists, especially Medinese and Kufans, are known to have taken different views: namely, that in such instances the state of ablution becomes invalid. Still, returning to some of the narrations on the subject associated with Ibn Hanbal it is recorded that he endorsed the view that the action 
This is the Accepted Version of an article published by Springer in International Journal for the Semiotics of Law - Revue internationale de Sémiotique juridique June 2016, Volume 29, Issue 2, pp 285-311. Please refer to published version when citing, available at: $10.1007 / \mathrm{s} 11196-016-9461-1$

Accepted Version downloaded from SOAS Research Online: http://eprints.soas.ac.uk/22374/

of lams, whatever the intention, would not nullify one's ritual ablution. Having gone through a morass of opinions on the subject, and cited a Prophetic tradition in which the Prophet's wife 'A $\bar{i}$ ' shah related that the Prophet kissed one of his wives before proceeding to the communal prayers, Ibn Qudāma explains that neither the tradition nor the Qur'ānic verse 'aw-lämastum al-nis $\bar{a}$ ' is pertinent to the discussions on the issue of obligation because the verse itself is concerned with actual sexual intercourse. In fact he refers to the lexical significance of the $m u f \bar{a}$ 'ala verbal form which retains connotations of reciprocal contact. It is at this juncture that he registers the fact that a third view is associated with Ibn Hanbal in which he stipulated that whatever the circumstances, the action of lams invalidates the status of one's ablution, noting that this was the position taken by al-Shāfi' $\overline{1}$ based on the generality of the Qur' ānic statement: 'aw-lāmastum al-nisä'. Ibn Qudāma explains that philologically, lams is designated as constituting the meeting of skin. He then includes a line of poetry to buttress the view alongside a reference to the concomitant Qur'ānic reading of the verse which is attributed to Ibn Mas' $\overline{\mathrm{ud}}$ : 'aw lamastum al-nis $\bar{a} \cdot{ }^{73}$ Significantly, the remainder of the discussions, which include references to further traditions, is taken up with the issue of the technical defects concerning the transmission of the 'kissing tradition' and whether the broader consideration of 'sexual desire' is more relevant when broaching the interpretation of the dicta. The upshot of this is that the concomitant readings of the verse are not the source of the actual disagreements on the main subject of ablution, but rather they sometimes permeate the arguments at subsequent stages of their analysis.

In the commentary of al-Tabarī the issue is treated at length but its significance turns not on any nuances between the two readings, but rather on whether the one reading, ' $a w$ lāmastum al-nisā', denotes touching or sexual intercourse. ${ }^{74}$ Initially, the extended discussions which feature in the text appear as a point of contention between groups of Arab and non-Arabs (mawālī) scholars, with even Ibn 'Abbās supposedly being asked to adjudicate as to whose opinion is correct. Included among the materials cited are narrations attributed to Companion and Successor figures who take the view that the verb lamastum encompasses a manifest reference to intercourse. Having listed the various reports in support of that view and its proponents, al-Ṭabarī quotes those scholars who take the opposing opinion that it merely connotes physical contact between a male and his partner and does not relate specifically to intercourse: 'al-lams $m \bar{a}$ dūn al-jimā', although figures who are cited in the supporting isnāds and sources have in cases already been recorded as proponents of the 
This is the Accepted Version of an article published by Springer in International Journal for the Semiotics of Law - Revue internationale de Sémiotique juridique June 2016, Volume 29, Issue 2, pp 285-311. Please refer to published version when citing, available at: $10.1007 / \mathrm{s} 11196-016-9461-1$

Accepted Version downloaded from SOAS Research Online: http://eprints.soas.ac.uk/22374/

opposite view. Among the many anecdotes there is a report attributed to Ibn Mas' $\bar{u} d$ which states 'the action of qubla (kissing) constitutes lams and necessitates ablution', along with a selection of similar views, but, in general, these have the 'aw-lämastum al-nisă' as their pivotal point of reference. The analyses of the import of attendant Prophetic traditions which are incorporated into al-Ṭabarì's treatment do not invoke the second reading 'aw-lamastum al-nis $\bar{a}^{\prime}$. In fact, having cited the different perspectives regarding the verses, al-Ṭabari mentioned the two different readings, attaching import to the fact that most Kufans favoured the reading without the alif, but al-Tabari does make it clear that both readings of the verse 'are proximate in terms of their meaning' and were, accordingly, both valid. ${ }^{75}$ It is evident that discussions about the issue do not appear to be anchored to the differences between the readings, although nuances were imported into the discussions once the relevant Prophetic and related dicta had been cited and deliberated upon.

In the commentaries of the Qur'ān which took as their focal point the ayyāt al-ahkām, notably the works of al-Ṭahāwī (d. 321/933), Abū Bakr al-Jașșās (d. 370/981), al-Kiyā alHarrāsī (d. 504/1110), Ibn al- 'Arabī, and al-Qurțubī (d. 671/1272) similar patterns are discerned with regards to this specific verse. Al-Qurțubī's treatment of the verse does commence with a break down of the different readings, scrutinising the semantic and lexical variances between the versions. He clarifies that 'aw-lamastum al-nisa', without the alif has three meanings: sexual intercourse; getting intimate with someone; and a third meaning which combines both meanings and that most scholars espoused the view that the expression lāmastum al-nis $\bar{a}^{\prime}$ has that meaning too, although exceptionally, Muhammad ibn Yazīd is said to have argued that the semantic compass of lamastum signified 'kissing' or comparable actions which are implicitly reciprocal. ${ }^{76} \mathrm{He}$ also draws the distinction that with regards to the philological tenor of lamastum, women remain ostensibly impassive. Again, the distinctions between the two readings are readily discerned but it would be difficult to assert that they are fundamental to the ensuing legal turns within the discussions. In fact al-Qurtubī explains that jurists differed over the implication of the verse, offering an invigorating overview of the different standpoints and their rationale. Displaying his Mālikī leanings, he declares the view that the active participle mulämasa is an act less than actual intercourse, adding that the caliph 'Umar, his son 'Abd Allāh and Ibn Mas'ūd all took that view; he comments that most of the leading jurists concurred with the opinion. The jurist Ibn al-'Arabī focuses upon the sequence of topics within the verse, namely, 'being ritually impure'; 
This is the Accepted Version of an article published by Springer in International Journal for the Semiotics of Law - Revue internationale de Sémiotique juridique June 2016, Volume 29, Issue 2, pp 285-311. Please refer to published version when citing, available at: $10.1007 / \mathrm{s} 11196-016-9461-1$

Accepted Version downloaded from SOAS Research Online: http://eprints.soas.ac.uk/22374/

'having relieved oneself'; and having had 'contact with one's partner'. He deduces that in the first instance its context is sexual intercourse; the second correlates with lesser ritual impurity; and the third implies simply touching or kissing. He argues to claim that the theme of intercourse (jima $)$ is the axial motif for the matrix of discussions within the verse would imply repetitiveness. ${ }^{77}$ Most of the ensuing passages are focused on reviewing the position taken by Abū Hanīfa, which restricts mulämasa to intercourse and dismisses the need for ablution in instances of touching, and the fact that his view was in contravention of the opinion attributed to the father of the Kufans' legal heritage Ibn Mas 'ūd, a point picked up by Ibn al- Arabī, who explains that the two concomitant readings are not in opposition. ${ }^{78}$ The labyrinth of discussions is impressively detailed and replete with counter arguments, but it is eye-catching that these are not firmly moored to the citation of the alternative reading of the verse, which is not mentioned among the plethora of detail. Again, it seems reasonable to conclude that the semantic nuances between the two separate variant readings of this verse were not the cause of the sinuous discussions which took place over their legal implications, but rather the different legal interpretations as referenced to debates within the Prophetic sunna were irrevocably driving the discourses. Burton does mention that classical scholarship was 'fully alive to the import of variant readings', quoting al-Suyūṭ̂̄ who avers that 'the differences in the readings signal the differences in the legal rulings', but such vaunted assertions are not fully substantiated by the sources. ${ }^{79}$ In fact even in works such as Ibn al'Arabi's Qānūn al-ta'wil, al-Zarkashī's Burhān, and the Itqān, materials devoted to the subject are meagre. Suggestively, even in the later legal manuals and mukhtașars the reference to the variant was altogether bypassed in the discussions. Ibn Rushd's Bidayat almujhtahid has a brief section devoted to 'Statements Concerning the Need for Ablution in Cases Where a Women Has Been Touched by Hand'. He offers an abridgement of the views including references to those who argued that qubla presupposes lams and warrants ablution, whether this was accompanied by feelings of pleasure or regardless; the views of the Shāfi ite and Mālikite scholars are listed. ${ }^{80}$ He then contrasts those views with the opinions attributed to Abū Hanifa who is identified with the opinion that lams al-nis $\bar{a}^{\prime}$ did not make ablution mandatory. Characteristically, Ibn Rushd laconically states that each view has its point of reference and source; however, he also attributes the reason for differences to the homonymity of the term lams in Arabic and that it can separately connote touching and sexual intercourse. The arguments about the weakness of certain traditions, including the 
This is the Accepted Version of an article published by Springer in International Journal for the Semiotics of Law - Revue internationale de Sémiotique juridique June 2016, Volume 29, Issue 2, pp 285-311. Please refer to published version when citing, available at: $10.1007 / \mathrm{s} 11196-016-9461-1$

Accepted Version downloaded from SOAS Research Online: http://eprints.soas.ac.uk/22374/

statement linked to ' $\overline{\mathrm{A}}$ ' isha, are weighed up; however, there is no graphic reference to the seemingly proximate variant readings of the verse as the source of the differences within the legal discussions.

\section{Purity and the Cessation of Menstruation}

The concomitant variant readings of Q. 2:222 did form the backdrop for elaborate discussions concerning differences over the rules about the end of menstruation and the conditions for resuming intimate relations with one's spouse. The Qur'ān states that: 'They ask you about menstruation. Say (to them), "therein lies impairment", so withdraw from women during such times. Do not approach them until they are purified; and when they are cleansed, approach them in the way decreed by God. Verily, God loves the repentant and those who are purified'. The operative term in the discussion relates to the imperfect verb, 'attaining purity' (yațurna). Ibn Mujāhid records that the lectio of Ibn Kathīr, Nāfi', Abū 'Amr and Ibn 'Āmir is yațurna, which was also attributed to 'Āṣim via Hafṣ; whereas, Hamza, al-Kisā' $\overline{1}$, and 'Aș̣im, in a second narration, read yațtahharna, where both the $t \bar{a}$ ' and the $h \bar{a}$ ' are geminated (mushaddada) as opposed to being mukhaffafa. ${ }^{81}$ According to al-Ṭabarī, those who favoured reading with takhfif (yathurna), inferred from the verse that a menstruating woman should only be approached intimately once the period is completed and blood ceases to flow. ${ }^{82}$ In contrast he explains that the second reading was interpreted as signifying their having also 'washed and purifying themselves'. The implication is that it was not freely linked to the cessation of blood. Al-Ṭabarī then includes three individual reports which separately link the stem of the flow of blood with attaining purity. Turning his attention to the second views: namely, those which favoured the geminated reading, he explains that they understood that it signified their 'purifying themselves with water'. A morphological explanation ensues whereby al-Ṭabari explains that the yattahharna verbal construction is originally derived from a process of assimilation: the $t \vec{a}^{\prime}$ has been integrated by the $t \bar{a}^{\prime}$ because of the phonological proximities of their points of articulation: as it was originally yatatahharna. And indeed it is this reading which he endorses as being the more apposite one: namely, it connotes their 'purifying themselves with water'. But he also summons the 
This is the Accepted Version of an article published by Springer in International Journal for the Semiotics of Law - Revue internationale de Sémiotique juridique June 2016, Volume 29, Issue 2, pp 285-311. Please refer to published version when citing, available at: $10.1007 / \mathrm{s} 11196-016-9461-1$

Accepted Version downloaded from SOAS Research Online: http://eprints.soas.ac.uk/22374/

issue of the general consensus among scholars that it was prohibited for a man to approach his wife (with sexual intent), following the end of her period, until she had appropriately cleansed herself. ${ }^{83}$ However, with regards to the geminated Qur' ānic reading of the verse, alȚabari then moves on to explain that scholars differed over what purification entailed: some stated it was washing with water and that it was inappropriate for a husband to approach his partner until she had cleansed all her body; others asserted that it was simply the performance of ablution before prayer; while, a third party maintained that it was based on the washing of the private parts which, once completed, resulted in purification, following which a husband was entitled to approach her with intimate intent. There is some historical context to this as it is explained that in the pre-Islamic periods if women ware menstruating, they were effectively ostracised, not being allowed to eat, drink or share the home with their spouses. ${ }^{84}$ Invoking the consensus among scholars that it was not licit for a husband to approach his wife until she had purified herself with water, al-Ṭabari infers that the most credible reading of the two must be the one which has the greater propensity to obviate ambiguity in the mind of a listener; whereas, conversely, the alternative reading does not guard against creating uncertainty as far as a listener is concerned, leading him to believe that it is possible for the partner of a menstruating spouse to initiate intimate contact with her immediately at the end of the period of menstruation. ${ }^{85}$ Al-Ṭabari concludes that for the aforementioned reasons he prefers the geminated reading of the verse. There does exist an evident antithesis between these two readings of the verse, although there is little in the form of argumentation used to underpin the first reading. An interesting discussion of the same verse ensues in al-Qurțubî̀s $J \bar{a} m \bar{\imath}^{-}{ }^{86} \mathrm{He}$ explains that in both the muṣhafs of Ubayy and Ibn Mas'ūd, the reading is vocalised as yatatahharna (the non-assimilated form); and that Anas ibn Mālik's codex had an interpolated treatment of the verse. Al-Qurțubī simply quotes the summary view offered by al-Tabarī. There is certainly no detailed analysis of the nuances between the two readings but rather the differences over the legal interpretation of the geminated reading (yattahharna) form the core of his discussions. ${ }^{87}$ The Andalusian scholar Abū Hayyān (d. 745/1344) insisted that the reading attributed to Anas ibn Mālik should be viewed as being exegetical as opposed to Qur' ānic on account of its flagrant contravention of the skeletal text. ${ }^{88}$

The Requirements of Ablution: the Washing or Wiping of the Feet 
This is the Accepted Version of an article published by Springer in International Journal for the Semiotics of Law - Revue internationale de Sémiotique juridique June 2016, Volume 29, Issue 2, pp 285-311. Please refer to published version when citing, available at: $10.1007 / \mathrm{s} 11196-016-9461-1$

Accepted Version downloaded from SOAS Research Online: http://eprints.soas.ac.uk/22374/

The question of whether it was requisite to wipe or wash the feet as part of the ritual ablution is often invoked as a locus classicus which illustrates the effective significance of legal differences wrought by the existence of concomitant variant readings. ${ }^{89}$ The discussions have their origins in the Qur'ānic discussions about the performance of ablution as set out in part of Q. 5:6, in which it is stated: 'Oh you who do believe, whenever you intend to pray, then wash your faces and hands up to the elbows; and wipe your heads; and ('wipe' or 'wash') your feet up to the ankles, and, if you are in a state of greater ritual impurity, then cleanse yourselves'. The semantic countenance of the verse turns on the grammatical status of the reading arjulikum or arjulakum (your feet) and whether it is grammatically coordinate with the preceding 'wipe your heads' construction; or conversely, whether it is syntactically conjoined to the opening segment of the verse which states 'wash your faces and hands'. The differences over the vocalization are summarized in the Kitāb al-Sab 'a: Ibn Mujāhid records that readers differed over the accusative or oblique reading of the läm in arjulikum or arjulakum. Ibn Kathīr, Hamza and Abū 'Amr all read in the oblique case (arjulikum) and Nāfī', Ibn 'Āmir and al-Kisā'̄ in the accusative (arjulakum). There exist two narrations on ‘Āṣim's reading: Hafṣ transmits the accusative reading (arjulakum), while Abū Bakr al'Ayyāsh attributes the oblique (khaf̣̣) reading, arjulikum, to him. ${ }^{90}$

The jurisprudential implications of this reading are forensically introduced by alȚabarī. Having dealt with issues raised with regards to the former part of the verse, he explains that the Hijāzī and Irāqī readers favoured the naṣb reading, before listing its implications. Explicitly, that the reading signifies washing (ghasl) your faces and your hands to your elbows; and (washing) your feet to the ankles; and wiping your heads. He even muses that the lexical arrangement exhibits a form of hyperbaton, with arjulakum being transferred within the verse order, yet syntactically conjoined to the term 'hands' in the 'wash your faces and hands', taking the same accusative ending. With reference to the reading, a range of dicta is adduced to support the ghasl explanation, including reports in which the practice of washing the feet is shown to be the accepted norm for ablution; and there are further exegetical remarks which refer to the phenomenon of hyperbaton (taqdim wa-ta'khīr), which the verse exhibits. ${ }^{91}$ Having covered the nașb reading, al-Ṭabarī then turns his attention to the second reading, arjulikum, explaining that, syntactically, those who read the term with the oblique ending, infer from it that the term is coordinate with the segment of the verse in 
This is the Accepted Version of an article published by Springer in International Journal for the Semiotics of Law - Revue internationale de Sémiotique juridique June 2016, Volume 29, Issue 2, pp 285-311. Please refer to published version when citing, available at: $10.1007 / \mathrm{s} 11196-016-9461-1$

Accepted Version downloaded from SOAS Research Online: http://eprints.soas.ac.uk/22374/

which 'wipe your heads' is mentioned. Correspondingly, reports which support the 'wiping' practice are discussed at length and explored within the context of the reading. Having discussed both the readings and summarized the reports in favour of both readings, al-Ṭabari expresses his own preference for the oblique reading, explaining that the issue of proximity dictates that it was more logical for the term 'arjulikum to be conjoined to the 'wipe your heads' construction and that it syntactically governed its inflection. Notwithstanding this fact, al-Tabarī contends that there is a generality as opposed to a specificity in which the term wipe or 'mash' was intended to be understood: namely, that it encompasses both wiping and washing. ${ }^{92}$ A selection of Prophetic traditions is cited to drive home his argument. The account provided by al-Tabarī implies that there is not necessarily an antithesis between the two readings as far as their respective import is concerned, although the different readings did attract much debate in the legal literature. ${ }^{93}$ It was the Basran grammarian Abū Jā far alNaḥhās (d. 338/950) who claimed that the two readings were akin to two separate verses. ${ }^{94}$ Burton did profess that such readings were part of the demand for Islamic documentation which was fuelled by incessant school rivalry. He argues that 'the Qur'ān was flexible only within exiguous limits' due to the authority of the standardized text, so scholars were 'driven to seek the liberties they craved in varying vocalic data (arjulakum/arjulikum), or the diacritic pointing (yațurna/tațtahirna (sic.)). And, he argues, apart from this, the only other resort open to them was textual interpolation. ${ }^{95}$ There are certainly comcomitant readings which produced opposing legal rulings, although the frequency with which they occur is somewhat confined. They are far outweighed by those readings which are univocal.

\section{Expiatory Fasting for Breached Oaths}

The penalty for the expiation of oaths is set out in the passage of Q. 5:89, where it is stated that 'God does not hold it against you for your carelessly gratuitous taking of oaths, but only those taken in earnest; the expiation for breaking an oath is to feed ten poor people, providing them with food that you would averagely afford for your own families; or to supply them with clothes or to set free a slave; those individuals without the means (to do so), should fast for three days; this is the expiation for breaching oaths but do try to keep them.' The question of whether the expiatory fasting of three days should be consecutive or separated 
This is the Accepted Version of an article published by Springer in International Journal for the Semiotics of Law - Revue internationale de Sémiotique juridique June 2016, Volume 29, Issue 2, pp 285-311. Please refer to published version when citing, available at: $10.1007 / \mathrm{s} 11196-016-9461-1$

Accepted Version downloaded from SOAS Research Online: http://eprints.soas.ac.uk/22374/

was examined among jurists. It was the Kufans and Hanafĩs scholars who were associated with the view that the fast for three days should be consecutive. In a section devoted to oaths al-Jașșāṣ takes up the discussion on the verse. He briefly records that the exegete Mujāhid narrated on the authority of Ibn Mas 'ūd, and the Medinan exegete Abū'l- 'Āliya al-Riyāhi on the authority of Ubayy, that they both read this verse as 'Thalāthati ayyām(in) (mutatābi 'ât)', where the last term is additional to the standard 'Uthmānic codices. ${ }^{96} \mathrm{He}$ also includes a statement attributed to the jurist Ibrāhīm al-Nakha' $\overline{1}$ clarifying that 'in our reading it is ' $\mathrm{Fa}$ șiyām thalāthati ayyām(in) mutatābi 'āt'. Al-Jașșāṣ then quotes Ibn 'Abbās, Mujāhid, Ibrāhīm (al-Nakha'ī), Țāwūs (d. 106/724), and Qatāda (d. 118/736) as all stating that 'separating between the days is not accepted', and accordingly 'that consecutiveness is required therein'. He maintains that on the basis of the positions taken by the aforementioned scholars consecutiveness is affirmed as being obligatory; however, al-Jașșāṣ offers an intriguing observation that the actual 'recitation' (tilāwā) of the verse cannot be confirmed due to its being abrogated; yet he makes it plain that its legal ruling remained valid, noting that this was the position taken by the madhhab. He confirms that both Mālik and al-Shāfī' 1 were of the view that 'interruption (of the expiatory days) was acceptable'. ${ }^{97}$ The explanation that the reading was abrogated but its ruling still valid is used to justify the position on consecutiveness, although the reading is cited. The matter is taken up further in al-Qurțubì's Jāmi ${ }^{\prime}$, where he explains that al-Shāfi 'î was supposed to have upheld two different views on this. Referring to al-Muzanī (d. 264/878), al-Qurțubī notes that he reached the same view by way of analogy, using the expiation for zihār (repudiation of one's wife) as his analogue and also deferring to the reading of Ibn Mas 'ūd. In a second opinion on the subject attributed to al-Shafi ' $\overline{1}$ and Mālik, the implementation of the fast on separate days is viewed as being permitted. The point is made that the action of consecutiveness being attributional rests on there being present a stipulated text or an analogy governed by such a text, yet these are absent in this instance. ${ }^{98}$ No mention is made of the issue of abrogation; the reading of Ibn Mas' 'ùd was presented as supporting evidence. In his Kitāb al-Ușūl al-Sarakhsī (d. 483/109091) does attempt to grapple with reconciling the Ibn Mas' $\bar{u} d$ reading with the notion of the mutāwātir status of the Qur'ān. ${ }^{99}$ He reports that given the fact that the lectio in which the term consecutive is used was associated with Ibn Mas 'ud, one can only assume that it was part of the original wording which was preserved in his reading but then withdrawn, placing its absence in the final texts within the vector of theories connected with abrogation. Yet, at 
This is the Accepted Version of an article published by Springer in International Journal for the Semiotics of Law - Revue internationale de Sémiotique juridique June 2016, Volume 29, Issue 2, pp 285-311. Please refer to published version when citing, available at: $10.1007 / \mathrm{s} 11196-016-9461-1$

Accepted Version downloaded from SOAS Research Online: http://eprints.soas.ac.uk/22374/

the same time, al-Sarakhsī like other jurists, simply points out that it (the reading) retains its value as an isolate report (shädhdha), functioning in the same way an alternative Prophetic dictum might be adduced. He elaborates further by stating that the reading remained wellattested (mashhüra) until the era of Abū Hanīfa and therefore Ibn Mas' ūd must have preserved the pre-abrogated lectio. As al-Zarkashī points out in his al-Bahr al-muhịt, the reasoning is that the lectio was once Qur'ānic in status, but then this status was revoked by its being abrogated, leading to the obliteration of its skeletal trace such that it was transmitted in an isolate mode, despite its retaining its legal efficacy. ${ }^{100}$ Intriguingly, with regards to Q. 2: 180 , and the reference in the verse to making up for days missed during the month of Ramadan, Hanafìte scholars did not stipulate consecutiveness, although a very similar type of textual addition to the standardized reading was attested in the codex of Ubayy: 'fa- iddat(un) min ayyām(in) ukhar (mutatābi 'ât). Significantly, there are analogous examples of textual interpolation and instances of abrogated readings whose legal authority endured and these feature prominently in legal discussions. They include, for example; the penalty for adultery (al-shaykh wa'l-shaykha); inheritance (al-walad li'l-firash); consanguinity and the impediments of suckling, whose tilāwa and hukm have supposedly been eliminated; the status of șalāt al-'aṣr as the șalāt al-wusțā (Q. 2:238); the exegetical gloss in Q. 4:12 which qualifies the kaläla verse; and even lectiones which have no legal import whatsoever such as the verses which were associated with the slaughter of the qurrā' at $\mathrm{Bi}^{\prime} \mathrm{r} \mathrm{Ma}$ ' una. ${ }^{101}$

In his monograph on the collection of the Qur'ān Burton did deal with the importance of this particular instance of Ibn Mas' ūd's variant, citing a further relevant reading Q. 4:24, attributed to Ubayy, which was pertinent to the law of marriage. He stated that it was of "the highest significance to the incessant inter-madhhab polemic whether one read Q. 5.89 or Q. 4:24 with or without 'Abdullāh's or Ubayy's reported interpolations'. ${ }^{102}$ And in this vein he concluded that such readings retained a counter-sunna function and were integral to the pursuit of specified legal arguments. His view was that the construct of an 'Uthmānic collection was used to counter religious practice substantiated through post- 'Uthmānic codices and that the science of abrogation was formulated to surmount the so-called contradictions arising from the original configuration of the text. It is undoubtedly true that while there are instances where different concomitant readings were judiciously imported into legal discourses and analyses, the idea that they are critical to the inter-madhhab polemic is less than clear-cut. Admittedly, Burton was interested in explaining such variations in the 
This is the Accepted Version of an article published by Springer in International Journal for the Semiotics of Law - Revue internationale de Sémiotique juridique June 2016, Volume 29, Issue 2, pp 285-311. Please refer to published version when citing, available at: $10.1007 / \mathrm{s} 11196-016-9461-1$

Accepted Version downloaded from SOAS Research Online: http://eprints.soas.ac.uk/22374/

legal materials through the lens of the earlier years of the development of legal thought and the embryonic nature of the strategies used by jurists, with the later periods representing the age of consolidation and rationalization. However, even within the earliest available treatises which comprise references to legal and exegetical arguments, the attestation of concomitant readings and other connected variants appears to have a subordinate function within legal discourses; notwithstanding the fact that the core Qur'ānic readings were the integral elements upon which the legal discourses were invariably based, concomitant readings yielding conflicting legal rulings tended to be the exception as opposed to the rule.

\section{Conclusions}

The body of variant readings forms an important element of classical legal discourses. However, the notion that the opposition between certain lectiones, particularly in terms of concomitant or consecutive variants, was engendered by legal debates and disputes is not demonstrated by the sources. Certainly, there are readings of verses which produce conflicting legal standpoints, but these appear infrequently. Moreover, had these materials been the products of inter-madhhab polemics, one would have expected their generation to have been exponentially more prolific and their influence within legal argumentation to have been much more acute. The nature of the materials suggests the contrary to be the case. Indeed, the regularity with which slightly divergent or dissimilar lectiones are cited in legal disputes appears disproportionate when measured against the vast body of readings and the classical juridical literature; despite the morpho-phonological and morpho-syntactic variances between such readings, univocality tends to be a characteristic of many of these consecutive lectiones. It is even evident that within legal discussions which highlight concomitant variants with conflicting legal implications, Prophetic reports and related dicta dominate the ensuing deliberations. The assertion that Companion readings had an incontrovertibly post'Uthmānic provenance remains open to question. The existence of the vast corpora of readings, including the non-canonical materials, were the veritable remnants of assiduously applied processes of transmission and preserved as such for posterity, remaining important sources for the history of the text of the Qur'ān. That such a vast body of material was preserved serves as testimony to the success of the imposition of the 'Uthmānic codices 
This is the Accepted Version of an article published by Springer in International Journal for the Semiotics of Law - Revue internationale de Sémiotique juridique June 2016, Volume 29, Issue 2, pp 285-311. Please refer to published version when citing, available at: $10.1007 / \mathrm{s} 11196-016-9461-1$

Accepted Version downloaded from SOAS Research Online: http://eprints.soas.ac.uk/22374/

which were constellated around the construct of accommodation; it was an endeavour that proved to be enduring.

\footnotetext{
I 'Abd Allāh ibn Abī Dāwūd Sulaymān Ibn Ash'ath al-Sijistānī, Kitāb al-Mașāhif, (ed.), M. Wā’iž. 2 vols in 1 (Beirut: Dār al-Bashā'ir al-'Islāmiyya, 2002). Also see Arthur Jeffery, Materials for the History of the Text of the Quran (Leiden: E. J. Brill, 1937). Abū Bakr and 'Umar are described as having 'brought the Qur'ān together between 'lawhayn', see Kitāb al-Mașāhif, vol. 1. P. 153 ff. Classical legal schools took different positions with regards to dealing with old, worn, frayed, or damaged Qur'ān/codices: among some classical jurists the view was that attempts should be made to repair them; where this was not possible due to their poor state, then, they should be wrapped in fabric and buried in a place where they will not be desecrated or subject to disrespect; this was the position of the Hanbalite and Hanafite jurists. Shāfi īte and Mālikite jurists stated that when such materials are beyond repair or restoration, they can be burnt on the basis that Uthman sanctioned the practice when compiling the standardised version of the text. The underlying rationale for such acts is that one is attempting to save such materials from desecration or violation as their content is sacred and sacrosanct. Al-Zarkashī, Badr al-Dīn Muhammad ibn Bahādir. al-Burhān fì 'ulūm al-Qur'ān. Edited by Muḥammad Abū'l-Faḍl Ibrāhīm, 4 Vols. Cairo: Dār al-Turāth, n.d. vol. 1, pp. 157-69.
}

2 'Abd Allāh ibn Abī Dāwūd Sulaymān Ibn Ash 'ath al-Sijistānī, Kitāb al-Mașāhifi, vol, 1 p. 148. An aversion to the writing down of anything other then scripture is recorded in the traditions. In fact in one specific hadīth the Prophet is said to reported to have remarked that 'Write down nothing which I utter other than the Qur'ān. If someone has written down something uttered by me other than the Qur'ān, then let him erase it.'For more on the opposition to the writing down of traditions see the arguments of Gregor Schoeler. The Oral and the Written in Early Islam. Tr. Uwe Vagelpohl, edited by James Montgomery. London: Routledge, 2006. He argues that the debate about opposition to writing down traditions 'came into full swing only around the turn of the first to the second century (720 AH) and lasted for several decades'. P. 125, and he reckons that it begun with the appearance of traditions which repulsed the practice of writing ahädith. Also note the Review Article of the book by Mustafa Shah in Journal of Qur'anic Studies (2008:10.1) pp. 98-128. Then there is the detailed study of the issue by Michael Cook, entitled: 'The Opponents of the Writing of Tradition in Early Islam.' Arabica (1997:44), pp. 437-530. Also note the work of Harald Motzki, ' Quo vadis HadithForschung? Eine kritische Untersuchung von G.H.A. Juynboll: "Nafi" the mawlā of ibn 'Umar; and 
This is the Accepted Version of an article published by Springer in International Journal for the Semiotics of Law - Revue internationale de Sémiotique juridique June 2016, Volume 29, Issue 2, pp 285-311. Please refer to published version when citing, available at: $10.1007 / \mathrm{s} 11196-016-9461-1$

Accepted Version downloaded from SOAS Research Online: http://eprints.soas.ac.uk/22374/

his position in Muslim Hadìth literature' Der Islam 73 (1996:73), pp. 40-80 and pp. 193-231. It is worth noting that Schoeler explains that the maintenance of an oral tradition supposedly provided greater latitude and flexibility in the interpretation of law but in reality the issue turns not on the means of knowledge transmission and preservation but rather attitudes to interpretation.

${ }^{3}$ Ibn al-Jazarī, Muhammad ibn Muḥammad al-Dimashqī. al-Nashr fì'l-qirā'āt al- 'ashr. (ed.), 'Alī Muhammad al-Ḍabbā' (2 vols. Beirut: Dār al-Kutub al-' Ilmiyya, n.d.), vol. 1 pp. 7-8.

${ }^{4}$ al-Bukhārī, (Bāb Jam 'al-Qur'ān in Kitāb faḍa'̄ōl al-Qur'an (pp. 432ff)). In Al-Kutub al-Sitta: Mawsū 'at al-ḥadīth al-sharīf. (ed.), Șāliḥ ibn 'Abd al-Azīz Āl-Shaykh. Riyāḍ: Dār al-Salām, 1999. p. 432. Discussions about the jami 'al-Qur'ān feature in Abū Bakr al-Bāqillānī's al-Intișār li'l-Qur'ān. (ed.), M. al-Quḍāh, 2 vols. (Beirut: Dār Ibn Hazm, 2001); cf. al-Sakhāwī, 'Alī ibn Muhammad, Jamāl al-Qurrā' wa-kamāl al-iqrāa'. (ed.), 'Alī Husaīn al-Bawwāb (Mecca: Maktabat al-Turath, 1987).

${ }^{5}$ al-Sijistānī, Kitāb al-Maṣāhịf, , 1. p. 178.

${ }^{6}$ al-Sijistānī, Kitāb al-Mașāhif, 1. pp. 178-9; cf. Ibn al-Jazarī, al-Nashr p. 433; Michael Cook, 'The Stemma of the Regional Codices of the Koran', Graeco-Arabica (2004:9-10): pp. 89-104.pp. 90-92.

${ }^{7}$ Abū 'Amr al-Dānī, al-Muqni' fì ma rifat marsūm mașāhịif ahl al-amșārr. (ed.), M. Dahmān (Damascus: Dār al-Fikr, 1983), p. 9.

${ }^{8}$ al-Dānī, al-Muqni, p. 15; cf. Al-Samhūdī, Nūr al-Dīn 'Alī, Wafā' al-wafā bi-akhbār dār al-Muṣtafā. 3 vols., (ed.), Muḥammad Muhyī al-Dīn 'Abd al-Ḥamīd. (Beirut: Dār al-Kutub al-'Ilmiyya, 1984), vol., 2. pp. 670-71.

${ }^{9}$ al-Dānī, al-Muqni, p. 15 and p. 88.

${ }^{10}$ Ibn 'Abd al-Barr, Al-Tamhīd li-mā fì'l-Muwattă' min ma 'ānī wa-asānīd. 26 vols. Various editors (vol. 8 Muhammad al-Falāḥ) (al-Maghrib: Wizarat al-Awqāf wa'l-Shu'ūn al-Islāmiyya, 1967-92). See the extended discussion on types of readings between pp. 280-315 (vol., 8. p. 293.

${ }^{\text {II }}$ According to the traditional sources, it was the companion 'Abd Allāh ibn Mas'ūd who was opposed to a standardised version of the text and his acute opposition is distinctive within the collection literature. He is reported to have declared that he was the most informed person with regards to the book of God, claiming to possess knowledge of not only how a verse was revealed but also the context of its revelation: al-Sijistānī, Kitāb al-Mașāhif,, 1. p. 182.

${ }^{12}$ Ibn al-Nadīm, al-Fihrist, ed. R. Tajaddud, 3rd edn. (Beirut: Dār al-Masīra, 1988), pp. 29-30; Ibn Khālawayhi, al-Husayn ibn Aḥmad, al-Hujja fìl'l-qirā'āt al-sab'. (ed.), 'Abd al-Āl Sālim Makram (Beirut: Dār al-Shurūq, 1971). Al-'Ukbarī, Abū'l-Baqā', I'rāb al-qirā'āt al-shawādhdh (Beirut: 'Ālam al-Kutub 1996) and Ibn Jinnī, Abū'l-Fatḥ, al-Muhtasab fì tabyīn wujūh shawādhdh al-qirā'āt wa'l-ịdāh 'anhā. (ed.), 'Alī al-Najdī Nāṣif, 'Abd al-Hālīm al-Najjār, 'Abd al-Fattāḥ Shalabī. 2 Vols. (Cairo: Lajnat Ihyā̄' al-Turāth al-'Arabī, A.H.1387).

${ }^{13}$ Al-Dānī, Abū 'Amr 'Uthmān ibn Sa īì. al-Muḥkam fì naqț al-mașāḥif. (ed.), 'Izzat Ḥasan, $2^{\text {nd }}$ edn. (Damascus: Dār al-Fikr, 1986), pp. 17-18. Al-Dānī mentions in the text the story of Mālik ibn Anas producing his grandfather's copy of a codex which was embellished in silver. 
This is the Accepted Version of an article published by Springer in International Journal for the Semiotics of Law - Revue internationale de Sémiotique juridique June 2016, Volume 29, Issue 2, pp 285-311. Please refer to published version when citing, available at: $10.1007 / \mathrm{s} 11196-016-9461-1$

Accepted Version downloaded from SOAS Research Online: http://eprints.soas.ac.uk/22374/

${ }^{14}$ Al-Farrā', Abū Zakariyyā', Yahȳā b. Ziyād, Ma 'ān̄̄ al-Qur'ān. 3 vols. Edited by Aḥmad Yūsuf Najātī and Muhammad 'Al̄̄ al-Najjār (Cairo, Dār al-Kutub al-Miṣriyya, 1955-72), vol. 3, pp. 172-3; cf. François Déroche, Qur'āns of the Umayyads: A First Overview. Leiden and Boston: Brill, 2014, p. 135 and Ibn al-Anbārī, Kitāb Ị̣̇̂h al-Waqf wa'l-ibtidā'. 2 vols (ed.), Muhyī al-Dīn 'Abd al-Rahmān Ramaḍān. Damascus: Majma` al-Lugha al-'Arabiyya, 1390/1971, vol. 1, pp. 39-42.

${ }^{15}$ Michael Carter: 'When Did the Word nahw First Come to Denote Grammar', Language and Communication 5(1985: 4), pp. 265-272. Carter questioned the value of the so-called biographical literature produced by linguists as he claimed there was not in them sufficient information to enable one to verify or analyse the so-called scholarship attributed to such figures.

${ }^{16}$ al-Bukhārī, (Bāb Jam 'al-Qur'ān in Kitāb faḍā' ìl al-Qur'an (pp. 432ff)). In Al-Kutub al-Sitta: Mawsū 'at al-ḩadīth al-sharīf. (ed.), Șāliḥ ibn 'Abd al-Azīz Āl-Shaykh. Riyāọ: Dār al-Salām, 1999, p. p. 433; Shady Hekmat Nasser, The Transmission of the Variant Readings of the Qur'ann: The Problem of Tawātur and the Emergence of Shawādhdh. Leiden and Boston: Brill, 2013. 71, Chapter 1 passim. And Abū Bakr al-Bāqillānī al-Intișār li'l-Qur'ān. (ed.), M. al-Quḍāh, 2 vols. (Beirut: Dār Ibn Hazm, 2001), vol. 1, p. 60. In his al-Ibāna 'an ma 'āñ̄ al-qirā'āt Makkī ibn Abī Țālib explained that if someone were to ask 'Do the Readings ( $q i r \bar{a}$ ' $\bar{a} t$ ) read by everyone today and attributed to the seven leading authorities: namely, Nāfî', 'Āṣim, Abū 'Amr and other figures, constitute the seven ahrüf whose recitation was permitted by the Prophet.' He goes on to mention it was he who said 'the Qur'ān was revealed in seven modes, so choose of these whatever pleases you?' Makkī then explains that readings which are in circulation today and whose transmission on the authority of the leading readers has been verified represent an aspect of the seven ahruf in which the Qur'ān was revealed'. Makkī ibn Abī Țālib, Abū Muḥammad. Ibāna 'an ma ān̄̄ al-qirāààt, ed. 'Abd al-Fattāḥ Shalabī (Cairo: Dār al-Ma'ārif, 1985), p. 34.

${ }^{17}$ Al-Qasțallānī, Shihāb al-Dīn, Lațā if al-ishārāt li-funūn al-qirā'āt. 2 vols. (ed.), 'Abd al-Ṣabūr Shāhīn and 'Āmir al-Sayyid 'Uthmān (Cairo: Lajnat Ihyā' al-Turāth al-Islāmī, 1972), vol.1, pp. 65f

${ }^{18}$ Shaykh al-Ṭā' ifa Abū Ja far Muhammad ibn al-Ḥasan al-Ṭūsī, Al-Tibyān fì tafsìr al-Qur'ān. 5 vols. Najaf: al-Maṭba at al-'Ilmiyya, 1957 (1376 A.H.), vol. 1, p. 7.

${ }^{19}$ See the discussions in the introductory sections of Ibn al-Jazarī, Muhammad ibn Muhammad alDimashqī, Ghāyat al-nihāya fì țabaqāt al-qurrā'. 2 vols. (ed.), Gotthelf Bergsträsser und Otto Pretzl (Cairo: Maṭba at al-Sa āda, 1935) and Shams al-Dīn al-Dhahab̄i, Ma 'rifat al-qurrā' al-kibār, (ed.), M. Jād al-Ḥaqq, $1^{\text {st }}$ edn (Cairo: Dār al-Kutub al-Ḥadītha, 1968).

${ }^{20}$ See for example Mustafa Shah, 'The Early Arabic Grammarians' Contributions to the Collection and Authentication of Qur'ānic Readings: The Prelude to Ibn Mujāhid's Kitāb al-sab 'a', Journal of Qur'ānic Studies 6:1 (2004), pp. 72-102 and Makkī ibn Abī Țālib, Kitāb al-Kashf 'an wujūh alqirā'āt al-sab '. (ed.), M. Ramāḍān (2 vols. Beirut: Mu'assasat al-Risāla, 1987); also Ibn Khālawayhi, al-Ḥusayn ibn Ahmad, al-Hujja fì'l-qirā'āt al-sab'. (ed.), 'Abd al-Āl Sālim Makram (Beirut: Dār alShurūq, 1971); and the relevant discussion in Shady Hekmat Nasser. 'The Two-Rāwī Canon Before and After ad-Dānī (d. 444/1052-3): The Role of Abū TTayyib ibn Ghalbūn (d. 389/998) and the Qayrawān/Andalus School in Creating the Two Rāwī Canon.' Oriens (2013:75.1.2), Pp. 41-75. p. 41. Mustafa Shah, 'The Early Arabic Grammarians' Contributions to the Collection and Authentication of Qur'ānic Readings: The Prelude to Ibn Mujāhid's Kitāb al-sab 'a', Journal of Qur'ānic Studies 6:1 (2004), pp. 72-102, passim 
This is the Accepted Version of an article published by Springer in International Journal for the Semiotics of Law - Revue internationale de Sémiotique juridique June 2016, Volume 29, Issue 2, pp 285-311. Please refer to published version when citing, available at: 10.1007/s11196-016-9461-1

Accepted Version downloaded from SOAS Research Online: http://eprints.soas.ac.uk/22374/

\begin{abstract}
${ }^{2 I}$ Mustafa Shah, 'The Early Arabic Grammarians' Contributions to the Collection and Authentication of Qur'ānic Readings: The Prelude to Ibn Mujāhid's Kitāb al-sab 'a', Journal of Qur'ānic Studies 6:1 (2004), pp. 72-102 for a detailed discussion of the issues. In that articles I suggested that 'Ibn Mujāhid's work was propelled into the limelight not only due to his prominence during the trials of Ibn Miqsam and Ibn Shannabūdh, but also because he was so influential as a teacher of readings among leading Bașran and Kūfan linguists'. The article also goes on to state that 'His work was not an attempt to arrest the proliferation of readings, but rather to reiterate the traditional axioms of readers, convincing his grammarian cohorts to dissipate their intellectual energy and expertise in the consummate defence of material which had enjoyed high levels of recognition and successive transmission, rather than indulging in hypothetical grammatical projection and pedantry; this they loyally executed.' See the discussion on P. 102.
\end{abstract}

${ }^{22}$ See the introduction to al-Ḥasan ibn Ahmad Abū 'Alī al-Fārisī. al-Hujja fì 'ilal al-qirā'āt al-sab ' 2 vols. (ed.), Shalabīin Nāṣīf, Najjār \& Najjā (Cairo: al-Hay'at al-Mișriyya, 1983) and Makkī ibn Abī Țālib, Kitāb al-Kashf 'an wujūh al-qirā'āt al-sab'. (ed.), M. Ramāḍān (2 vols. Beirut: Mu'assasat alRisāla, 1987). In such works phonological traits are discussed at length in the introductory discussions. This is also the case for the seminal Kitāb al-Sab ' $a$.

${ }^{23}$ See the range of treatments in al-Farrā', Abū Zakariyyā', Yạyā b. Ziyād, Ma 'ānī al-Qur'ān. 3 vols. Edited by Aḥmad Yūsuf Najātī and Muhammad 'Alī al-Najjār (Cairo, Dār al-Kutub al-Mișriyya, 1955-72); Ma 'mar ibn al-Muthannā Abū 'Ubayda, Majāz al-Qur'ān. 2 vols. (ed.), Fu'ād Sezgin, $2^{\text {nd }}$ edn (Beirut: Mu'assasat al-Risāla, 1981); al-Akhfash al-Awsaț, Ma 'ānī al-Qur'ān. 2 vols. (ed.), Fā'iz Fāris. 3rd edn. Kuwait: Dār al-Bashīr, 1981. I have pointed out elsewhere that these sorts of works which focused on a grammatical analysis of the Qur'ānic diction were criticised: see the discussion in Mustafa Shah (ed.), Tafsìr: Interpreting the Qur'ān, Critical Concepts in Islamic Studies (4 vols. London: Routledge, 2013), vol. 1, p. 14, where I note that 'The biographer al-Dāwūdī refers to an anecdote in which it is mentioned that Abū 'Ubayd al-Qāsim ibn Sallām (157-224/774-838) compiled an exegetical-grammatical treatise which fused the linguistic analyses of al-Farrā' and Abū 'Ubayda. It is reported that Ibn Sallām was apparently half-way through the text when he received a note from Ahmad ibn Hanbal, expressing his dismay to learn that "you are compiling a work on qir $\bar{a}$ ' $\bar{a} t$ in which you have established al-Farra' and Abū 'Ubayda as authorities in the area of ma 'ann $\bar{\imath}$ al-Qur'ān: refrain from this. He supposedly stopped working on the text.' (p. 14 of tafsìr) Al-Dāwudī, Shams al-Dīn Muḥammad ibn 'Alī. Tabaqāt al-Mufassirinn. Edited by A.M. 'Umar. 2 Vols. Cairo: Maktabat Wahba, 1977, vol. 1, pp. 105-7.

${ }^{24}$ Edmund Beck, 'Studien zur Geschichte der Kūfischen Koranlesung in den Beiden Ersten Jahrhunderten', Orientalia 17 (1948), pp. 326-55.

${ }^{25}$ al-Farrā', Abū Zakariyyā̄', Yahyyā b. Ziyād, Ma'ān̄̄ al-Qur'ān. 3 vols. Edited by Aḥmad Yūsuf Najātī and Muḥammad 'Alī al-Najjār (Cairo, Dār al-Kutub al-Miṣriyya, 1955-72), vol. 3, p. 68.

${ }^{26}$ Muhammad 'Abd Allāh ibn Muslim ibn Qutayba, Ta'wīl mushkil al-Qur'ān, ed. Aḥmad Ṣaqr, $2^{\text {nd }}$ edn (Cairo: Dār al-Turāth, 1973), pp. 51-52. Makkī takes the view that notwithstanding differences with regards to the processes of ikhtiya $\bar{r}$ or synthesis of readings, that there were three simple rules which governed selection: firstly, a reading's strong linguistic properties; its being in harmony with the established codex; and there bein the existence of sound consensus with regards to the status of the reading among authorities ( $i j m \bar{a}$ ' $a l$ - 'àmma). He even mentions that al- 'amma here refers to that 
This is the Accepted Version of an article published by Springer in International Journal for the Semiotics of Law - Revue internationale de Sémiotique juridique June 2016, Volume 29, Issue 2, pp 285-311. Please refer to published version when citing, available at: $10.1007 / \mathrm{s} 11196-016-9461-1$

Accepted Version downloaded from SOAS Research Online: http://eprints.soas.ac.uk/22374/

agreed upon by the Medinese and Kufans. Makkī ibn Abī Țālib, Abū Muḥammad. Ibāna 'an ma ān̄̄ al-qirāàt, ed. 'Abd al-Fattāḥ Shalab̄i (Cairo: Dār al-Ma'ārif, 1985), p. 101.

${ }^{27}$ Mustafa Shah, 'The Early Arabic Grammarians' Contributions to the Collection and Authentication of Qur'ānic Readings: The Prelude to Ibn Mujāhid's Kitāb al-sab 'a', Journal of Qur'ānic Studies 6:1 (2004), pp. 72-102, passim

${ }^{28}$ Shams al-Dīn al-Dhahabī, Ma 'rifat al-qurrā’ al-kibār, (ed.), M. Jād al-Ḥaqq, $1^{\text {st }}$ edn (Cairo: Dār alKutub al-Hadìtha, 1968), vol. 1, p. 94 and Mustafa Shah, 'Exploring the Genesis of Early Arabic Linguistic Thought: Qur'ānic Readers and Grammarians of the Kūfan Tradition.' (Part I). Journal of Qur'änic Studies (2003:5:1), pp. 47-78, p. 68. And see Mustafa Shah, 'Exploring the Genesis of Early Arabic Linguistic Thought: Qur'ānic Readers and Grammarians of the Bașran Tradition'. (Part II). Journal of Qur'ānic Studies, (2003:5:2) Pp. 1-48.

${ }^{29}$ Ibn Mujāhid, Kitāb al-Sab 'a fì-l-qirā' āt. (ed.), Shawqī Dayf. $2^{\text {nd }}$ edn., Cairo: Dār al-Ma'ārif, ca. 1401/1980, p. 68.

${ }^{30}$ Sībawayhi, Abū Bishr 'Amr ibn 'Uthmān. al-Kitāb. (ed.), 'Abd al-Salām Hārūn, 5 Vols. (Beirut: Dār al-Jīl, 1991), vol. 1, p. 59.

${ }^{31}$ Mustafa Shah, 'The Early Arabic Grammarians' Contributions to the Collection and Authentication of Qur'ānic Readings: The Prelude to Ibn Mujāhid's Kitāb al-sab 'a', Journal of Qur'ānic Studies 6:1 (2004), pp. 72-102. p. 74.

${ }^{32}$ Muhammad 'Abd Allāh ibn Muslim ibn Qutayba, Ta'wīl mushkil al-Qur'ān, ed. Aḥmad Ṣaqr, $2^{\text {nd }}$ edn (Cairo: Dār al-Turāth, 1973), p. 51.

${ }^{33}$ Mustafa Shah, 'The Early Arabic Grammarians' Pp. 78-9.

${ }^{34}$ See the range of examples in Aḥmad b. Muhammad al-Sayyārī, Revelation and Falsification: the Kitāb al-qirā' $\bar{a} t$ of Ahmad b. Muhammad al-Sayyārī. Critical Edition with an Introduction and notes by Etan Kohlberg and Mohammed Ali Amir-Moezzi. E. J. Brill, Leiden 2009. See also the review which states that 'In al-Sayyārī's introduction this construct of tahrîf (falsification) is presented through a series of fragmented statements: a number of these comprises seemingly oblique references to inconsistencies in the transmission of the originally revealed text; others are much more forthright, claiming that additions as well as omissions were an insidious feature of the officially redacted Qur'an. Kohlberg adds that 'it was doubtful whether al-Sayyārī's aim was to encourage his readers to recite the Qur'an in accordance with the qir $\bar{a}$ ' $\bar{t}$ t which he cited. Instead, he must have seen his task as that of recording and preserving those readings which the Imāmī community regarded as reliable', this is set out on p. 45 of Revelation and Falsification'. See the review in Bulletin of the School of Oriental and African Studies (2011:74.2), pp. 316-319.

${ }^{35}$ Abū 'Amr al-Dānī, Jāmi 'al-bayān fì al-qirā'āt al-sab 'al-mashhūra. (ed.), Muḥammad Ṣadūq alJazī’ irī (Beirut: Dār al-Kutub al- 'Ilmiyya, 2005), p. 38.

${ }^{36}$ John Wansbrough, Quranic Studies: Sources and Methods of Scriptural Interpretation (Oxford: Oxford University Press, 1977). pp. 44-5. Wanbrough's theories inexorably shaped current debates on the issue of Islamic origins, inspiring the study of the legal, theological and historical traditions of Islamic scholarship through the lens of the issue of authenticity. Wansbrough argued the 'Uthmannic 
This is the Accepted Version of an article published by Springer in International Journal for the Semiotics of Law - Revue internationale de Sémiotique juridique June 2016, Volume 29, Issue 2, pp 285-311. Please refer to published version when citing, available at: $10.1007 / \mathrm{s} 11196-016-9461-1$

Accepted Version downloaded from SOAS Research Online: http://eprints.soas.ac.uk/22374/

codex or Qur'an was simply a post third/ninth century occurrence 'composed from a conflation of Prophetic logia.'

${ }^{37}$ François Déroche, Qur'ans of the Umayyads: A First Overview. Leiden and Boston: Brill, 2014, p. 136.

${ }^{38}$ François Déroche, Qur'ans of the Umayyads: A First Overview. Leiden and Boston: Brill, 2014, p. pp. 6-8; and p. 14; also note Alba Fedeli, 'Variants and substantiated Qirā'àt: A Few Notes Exploring Their Fluidity in the Oldest Qur'ānic Manuscripts.' Pp. 403-27 in Die Entstehung einer Weltreligion, II. Edited by Markus Gross and Karl-Heinz Ohlig. Berlin: Verlag Hans Schiler, 2012. She cites Intisar Rabb's study of (Or. 2165), noting that Rabb had 'highlighted the fluidity and mobility of the qirā' $\bar{a} t$ tradition from its inception' (p. 404). This is a rather broad conclusion to draw on the basis of Rabb's work on the manuscript. For more on the ancient codices see Alphonse Mingana \& Agnes Smith Lewis, Leaves from Three Ancient Qurāns Possibly Pre-'Othmānic With a List of their Variants (Cambridge: CUP, 1914), pp. xxxiif. Estelle Whelan. 'Writing the Word of God: Some Early Qur'ān Manuscripts and Their Milieux', Part I, Ars Orientalis (1990:20), pp. 113-147. See discussion in the first chapter of Sheila Blair Islamic Calligraphy (Edinburgh : Edinburgh University Press, 2007). For samples see François Déroche, The Abbasid Tradition: Qur'ans of the 8th to 10th centuries (London: Nour Foundation in Association with Azimuth Editions and Oxford University Press, 1992). See also R. Hamdūn, al-Makhtūtạt al-Qur'āniyya fì Șan'à' mundhu al-qarn al-awwal al-hijrī. This is a Masters thesis published in Șan' $\bar{a}$ ', 2004.

${ }^{39}$ François Déroche, Qur'ans of the Umayyads: A First Overview. Leiden and Boston: Brill, 2014, p. p. 14; and E. Whelan, 'Evidence for the Early Codification of the Qur'ān', Journal of the American Oriental Society 118 (1998), p. 1-14; also see François Déroche, La transmission écrite du Coran dans les débuts de l'islam: Le codex Parisino-petropolitanus, Leiden and Boston: Brill, 2009. Note that Déroche had previously worked on the Le Codex Parisino-petropolitanus; this comprises fragments from a Qur'ānic manuscript discovered in the 'Amr ibn al- 'Āṣ mosque at Fustat. It is noted that he concluded that it was possible that the manuscript could be a copy of a much older codex. In terms of a timeline he posited that the third quarter of the $1^{\text {st }} / 7^{\text {th }}$ century was the probable historical period for its origin. He did argue that there were issues regarding the traditional accounts of the genesis of the 'Uthmānic codex in terms of their being seemingly inconsistent with 'technical possibilities of the Arabic script towards the middle of the $1^{\text {st }} / 7^{\text {th }}$ century' and that the caliph's role in establishing a vulgate may have been less ambitious than traditionally implied.' For more on this see Mustafa Shah (ed.) Tafsir: interpreting the Qur'an. It is pointed out there that 'Déroche does speculate that the Parisino-petropolitanus would have been subjected to emendation and corrections over a long time span and that this would have led to the eventual elimination of discrepancies.' Also see Werner Diem, 'Some Glimpses at the Rise and Early Development of the Arabic Orthography', Orientalia 45 (1976), pp. 251-61, p. 252 and Nabia Abbott, The Rise of the North Arabic Script and its Kur'anic Development (Chicago: University of Chicago Press, 1939). Beatrice Grundler The development of the Arabic Scripts. From the Nabatean Era to the First Islamic Century According to Dated Texts (Atlanta, 1993). Johannes Pedersen (trans. Geoffrey French, ed. R. Hillenbrand), The Arabic Book (Princeton, New Jersey: Princeton University Press, 1984). Some earlier studies of codices include Adolf Grohmann's 'The Problem of Dating the Early Qur'āns', Der Islam 33 (1958), pp. 213-31. And in general Adolf Grohmann, From the World of Arabic Papyri (Cairo: Al-Ma'ārif Press, 1952), pp. 82-5. cf. B. Moritz, Arabic Palaeography (Cairo: Bibliothèque Khédivale, 1905). 
This is the Accepted Version of an article published by Springer in International Journal for the Semiotics of Law - Revue internationale de Sémiotique juridique June 2016, Volume 29, Issue 2, pp 285-311. Please refer to published version when citing, available at: 10.1007/s11196-016-9461-1

Accepted Version downloaded from SOAS Research Online: http://eprints.soas.ac.uk/22374/

Puin, G. R. 'Observations on Early Qur'ān Manuscripts in Șan 'à'.' In The Qur'ān as Text. Edited by Stefan Wild. Leiden: E. J. Brill, 1996. pp. 107-11.

${ }^{40}$ Behnam Sadeghi and Goudarzi, Mohsen, 'Șan'à' 1 and the Origins of the Qur'ān,' Der Islam, 87(2011): pp. 1-129, p. 8; cf. Elisabeth Puin, 'Ein früher Koranpalimpsest aus Șan'à' (DAM 0127.1).' In Schlaglichter: Die beiden ersten islamischen Jahrhunderte. Edited by M. Gross and K-H. Ohlig, pp. 461-493. Berlin: Verlag Hans Schiler, 2008. pp. 461-3 and the general discussion in the study of Behnam Sadeghi and Bergmann, Uwe, 'The Codex of a Companion of the Prophet and the Qur'ān of the Prophet.' Arabica, 57 (2010): pp. 343-436.

${ }^{41}$ François Déroche, Qur'ans of the Umayyads: A First Overview. Leiden and Boston: Brill, 2014, pp. 48-54. It has been explained that C-14 tests confirm when the parchment was prepared but that in terms of the actual writing and script, establishing the date of the ink is so much more problematic. One respected scholar Sheila Blair, who has written extensively on codices and calligraphy, has pointed out to me that it is rare to have a time lag between the slaughter of animals and the subsequent use of their hides for parchment. But she also notes: 'But C-14 dating is tricky. You need to have a clean sample, and the typical way to clean is to use petroleum solvents, which can alter the date significantly'. Still, once they have been prepared, it is quite probable that such parchments would have been used immediately for transcription. The dates given for the folios are: AD 568 and 645 with $95.4 \%$ accuracy; the orthographical features of the text are consistent with the materials produced in much later periods (verses markers and separators are reported to have been a later introduction). The style and format of the actual orthography indicate that the Birmingham manuscript probably belongs to the Umayyad era (circa 661-700). Also, interestingly, the issue of orthography has been largely overlooked in the current media discussions. When it comes to the dating of Qur'ānic manuscripts of this nature, academic scholars such as Déroche will argue that much of the evidence for the history of the textual transmission of the Qur'ān still needs to be meticulously analysed and assessed, so it would be seemingly premature to talk about a rewriting of early Islamic history on the bases of these folios.

${ }^{42}$ In debates about the origins of the early Islamic literary sources and the Qur'ân it is argued that 'traditional' Muslim accounts about the collection of the Qur'ān were not only idealised and unreliable, but also that they were designed to create historical depth for the document of the Qur'ān. The theory is that the Qur'ān was only given fixed form in the late seventh century which was much later than the time specified in the traditional literature. Overall, this sceptical hermeneutic towards the traditional sources became an overarching paradigm of studies of the early Islamic literary disciplines which were referenced to the fact that the archival records of early Islam tended to be largely fragmental. The concern for academics was not that the teachings and beliefs enshrined in the Qur'ān and the Prophetic traditions (the reports recounting the words, deeds and directives of the prophet) were inauthentic or unsophisticated but rather that historically dating these materials to the period of the Prophet and his Companions was not possible. Even studies of disciplines such as law, grammar, theology and biography were beset by the contention that their original literary sources were unreliable as they were chiefly preserved in later texts and projected backwards. Some were the product of pseudepigraphic processes. Gradually, with the discovery and publication of folios and manuscripts, arguments for dating the Qur'ān to later periods in history gradually receded to the extent that it was no longer tenable to content that the Qur'ān appeared much later than claimed in the traditional narratives. However, while previously the concern within revisionist academic circles was one relating to the dating of the Qur' an and the teachings therein, the new paradigm turned on the suggestion that all the available manuscript evidence, including the recently dated Mingana manuscripts, do not seem to tally with the traditional Muslim accounts of the collection of the Qur'àn 
This is the Accepted Version of an article published by Springer in International Journal for the Semiotics of Law - Revue internationale de Sémiotique juridique June 2016, Volume 29, Issue 2, pp 285-311. Please refer to published version when citing, available at: $10.1007 / \mathrm{s} 11196-016-9461-1$

Accepted Version downloaded from SOAS Research Online: http://eprints.soas.ac.uk/22374/

(bearing in mind that these were preserved in the corpus of hadiths). The focus on so-called contradictions between the 'traditional accounts' and the actual text of the Qur'ann is completely misleading.

${ }^{43}$ John Burton, The Collection of the Qur'ān (Cambridge: Cambridge University Press, 1977), p. 186

${ }^{44}$ John Burton, The Collection of the Qur'ān (Cambridge: Cambridge University Press, 1977), p. 6.

${ }^{45}$ John Burton, The Collection of the Qur'ān (Cambridge: Cambridge University Press, 1977), p. 225.

${ }^{46}$ Harald Motzki, 'The Collection of the Qur'ān: a Reconsideration of Western Views in Light of Recent Methodological Developments' (2001) Der Islam pp. 2-34.

${ }^{47}$ Shady Hekmat Nasser, The Transmission of the Variant Readings of the Qur'an: The Problem of Tawātur and the Emergence of Shawädhdh. Leiden and Boston: Brill, 2013, p. 40.

${ }^{48}$ Al-Jașșāṣ, Abū Bakr, Ahkāmm al-Qur'ān, 3 vols. (ed.) 'Abd al-Salām Shāhīn. (Beirut: Dār al-Kutub al-'Ilmiyya, 1994), vol. 1, p. 116.

${ }^{49}$ Al-Jașṣāṣ, Abū Bakr, Aḥkām al-Qur'ān, 3 vols. (ed.) 'Abd al-Salām Shāhīn. (Beirut: Dār al-Kutub al-'Ilmiyya, 1994), vol. 1, p. 116; al-Qurțub̄î, Abū 'Abd Allāh Muhammad al-Anșārī, al-Jāmi' lì ahkām al-Qur'ān. 21 vols. Beirut: Dār al-Kutub al-'Ilmiyya, 1988, vol. 1 [pt. 2], pp. 120-23.

${ }^{50}$ Al-Farrā', Abū Zakariyyā', Yaḥyā b. Ziyād, Ma 'ān̄̄ al-Qur'ān. 3 vols. Edited by Aḥmad Yūsuf Najātī and Muḥammad 'Alī al-Najjār (Cairo, Dār al-Kutub al-Miṣriyya, 1955-72), vol. 1, p. 71.

${ }^{51}$ Al-Ṭabarī, Jāmi al-bayān 'an ta'wāl āy al-Qur'ān. 26 vols. (ed.), Abd al-Muḥsin al-Turkī in association with Markaz al-Buhūth wa'l-Dirāsāt al-'Arabiyya wa'l-Islāmiyya (Cairo: Dār Hajar, 2001), vol. 2. pp. 708-729.

${ }^{52}$ Al-Ṭabarī, Jāmi al-bayān 'an ta'wīl āy al-Qur'ān. 26 vols. (ed.), Abd al-Muḥsin al-Turkī in association with Markaz al-Buhūth wa'l-Dirāsāt al- Arabiyya wa'l-Islāmiyya (Cairo: Dār Hajar, 2001), vol. 2. pp. 708-729.

${ }^{53}$ Al-Ṭabarī, Jāmi al-bayān 'an ta'wīl āy al-Qur'ān. 26 vols. (ed.), Abd al-Muḥsin al-Turkī in association with Markaz al-Buhūth wa'l-Dirāsāt al- Arabiyya wa'l-Islāmiyya (Cairo: Dār Hajar, 2001), vol. 2. pp. 708- Al-Ṭabarī, Jāmi 'al-bayān 'an ta'wīl āy al-Qur'ān. 26 vols. (ed.), Abd alMuḥsin al-Turkī in association with Markaz al-Buhūth wa'l-Dirāsāt al- 'Arabiyya wa'l-Islāmiyya (Cairo: Dār Hajar, 2001), vol. 2. P. 726.

${ }^{54}$ Ibn Qudāma Muwaffaq al-Dīn. al-Mughnī fì fiqh al-imām Aḥmad ibn Hanbal al-Shaybān̄̄. 13 vols. (Beirut: Dār al-Fikr, 1985), vol. 3. p. 194.

55 'Alā al-Dīn al-Mardāwī, Al-Taḩbīr sharh al-tahrīr. 8 vols. Riyadh: Maktabat al-Rushd, 2001.

p. 1379 cf. Ibn Taymiyya, Ahmad b. 'Abd al-Halīm, Majmū' fatāwā shaykh al-Islam. 38 vols. (ed.), 'Abd al-Raḥmān b. Muḥammad b. Qāsim (Riyadh: Maṭba' at al-Riyāạ, 1961-74, vol. 13. pp. 392-95; al-Nawawī, Muhiyy al-Dīn, Al-Tibyān fì ādāb hamalat al-Qur'ān. (ed.), Muhammad Rị̣wān. Beirut, Mu'assasat al-Risāla, 2000, p. 152. Grammarians continued to debate the value of readings which conflicted with the mushaf. For example ones notes that when discussing Q. 20:63, al-Farrā' points out Abū 'Amr ibn al-'Alā's position regarding the lectio, referring to the fact that the latter had 
This is the Accepted Version of an article published by Springer in International Journal for the Semiotics of Law - Revue internationale de Sémiotique juridique June 2016, Volume 29, Issue 2, pp 285-311. Please refer to published version when citing, available at: $10.1007 / \mathrm{s} 11196-016-9461-1$

Accepted Version downloaded from SOAS Research Online: http://eprints.soas.ac.uk/22374/

endorsed a reading which differed with the standardized text. Al-Farra' disapprovingly remarks that 'I would not wish to contravene the kitāb (the mushaf)'. Al-Farrā', Abū Zakariyyā', Yahyā b. Ziyād, Ma 'ānī al-Qur'ān. 3 vols. Edited by Aḥmad Yūsuf Najātī and Muhammad 'Alī al-Najjār (Cairo, Dār al-Kutub al-Mișriyya, 1955-72).

${ }^{56}$ Ibn al-Jazarī, Muhammad ibn Muhammad al-Dimashqī. al-Nashr fì'l-qirā'āt al-'ashr. (ed.), 'Alī Muḥammad al-Ḍabbā' (2 vols. Beirut: Dār al-Kutub al- 'Ilmiyya, n.d.), vol. 1. pp. 9-15.

${ }^{57}$ Al-Isnawī, Jamāl al-Dīn, al-Tamhīd fì takhrīj al-furū' 'alā al-ușūl. (ed.), Ḥusayn Hitu (Beirut: Mu'assasat al-Risāla, 1986), p. 142.

${ }^{58}$ Ibn Qudāma, Muwaffaq al-Dīn. Rawḍat al-nāżir wa-junnat al-manāzir. (ed.), Sayf al-Dīn al-Kātib, 2nd edi., (Beirut: Dār al-Kitāb al-'Arabī, 1987), p. 61; 'Abd al-'Alīyy al-Mas'ūl, Al-qirā'āt alshādhdha: đ̣āwābițhā wa'l-ihtijāj bihā fì'l-fiqh wa'l- 'arabiyya (Cairo; Riyāạh: Dār ibn al-'Affān and Dār ibn al-Qayyim, 2008). p. 194 f.

${ }^{59}$ Ibn al-Hājib, Mukhtașar al-muntahā.( Cairo, 1326 A.H).

p. 50 .

${ }^{60}$ Ibn Ḥazm, al-Muhallā fì sharh al-mujallā bi'l-hijaj wa'l-āthār. (ed.) Ḥassān 'Abd al-Mannān. Ammān, Bayt al-Afkār, 2003, p. 679.

${ }^{61}$ Al-Isnawī, Jamāl al-Dīn, al-Tamhīd fì takhrīj al-furū' 'alā al-uṣūl. (ed.), Hiusayn Hitu (Beirut: Mu'assasat al-Risāla, 1986), p. 141f; 24, p. 200; 'Abd al-'Alīyy al-Mas'ūl, Al-qirā'āt al-shädhdha: ḍāwābituhā wa 'l-ihtijāj bihā fì'l-fiqh wa'l- 'arabiyya (Cairo;Riyāḍh: Dār ibn al- 'Affān and Dār ibn alQayyim, 2008).

${ }^{62}$ Ibn al-Nadīm, al-Fihrist, ed. R. Tajaddud, 3rd edn. (Beirut: Dār al-Masīra, 1988), p. 57; cf. Mustafa Shah, 'The Early Arabic Grammarians' Contributions to the Collection and Authentication of Qur'ānic Readings: The Prelude to Ibn Mujāhid's Kitāb al-Sab 'a', Journal of Qur'ānic Studies 6:1 (2004), pp. 72-102, p. 99.

${ }^{63}$ It is the misunderstanding concerning the literal meaning of tawätur which appears to lead to the confusion about the relevance of this term in the context of qir $\bar{a} ' \bar{a} t$ and their transmission by readers and their students.

${ }^{64}$ John Burton, The Collection of the Qur'ān (Cambridge: Cambridge University Press, 1977), p. 6, pp. 30-32, also in the same text p. 186.

${ }^{65}$ John Burton, The Collection of the Qur'ān (Cambridge: Cambridge University Press, 1977), 25, p. 228.

${ }^{66}$ Ibn Mujāhid, Kitāb al-Sab 'a fî-l-qirā'āt. (ed.), Shawqī Dayf. $2^{\text {nd }}$ edn. (Cairo: Dār al-Ma'ārif. 1401/1980), pp. 179-80.

${ }^{67}$ Al-Qurțubī, Abū 'Abd Allāh Muhammad al-Anșārī, al-Jāmi' lī ahkāam al-Qur'ān. 21 vols. Beirut: Dār al-Kutub al- 'Ilmiyya, 1988, vol. 1. [pt. 2], pp. 234-35. 
This is the Accepted Version of an article published by Springer in International Journal for the Semiotics of Law - Revue internationale de Sémiotique juridique June 2016, Volume 29, Issue 2, pp 285-311. Please refer to published version when citing, available at: $10.1007 / \mathrm{s} 11196-016-9461-1$

Accepted Version downloaded from SOAS Research Online: http://eprints.soas.ac.uk/22374/

${ }^{68}$ Ibn al- 'Arabī, Ahkām al-Qur'ān. 3 vols. (ed.), M. A. 'Ațā' (Beirut: Dār al-Kutub al- 'Ilmiyya, 1994), vol. 1. p. 152.

${ }^{69}$ Al-Qurțubī, Abū 'Abd Allāh Muhammad al-Anșārī, al-Jāmi' lī ahkām al-Qur'ān. 21 vols. Beirut: Dār al-Kutub al- 'Ilmiyya, 1988, vol. 1, [pt. 2], pp. 234-35; Al-Jașșāṣ, Abū Bakr, Ahkām al-Qur'ān, 3 vols. (ed.) 'Abd al-Salām Shāhīn. (Beirut: Dār al-Kutub al-'Ilmiyya, 1994), vol. 1. pp. 314-15. AlȘāliḥ̄, Abū Bakr, Tuhfat al-Rāki wa 'l-sājid bi-ahkām al-masājid. (ed.), Șāliḥ Sālim. Nahhām, et al. (Wizārat al-Awqāf wa'l-Shu' ūn al-Islāmiyya, 2004).

${ }^{70} \mathrm{Al}-\mathrm{T}$ abarī, Jāmi al-bayān 'an ta'wīl āy al-Qur'ān. 26 vols. (ed.), Abd al-Muhsin al-Turkī in association with Markaz al-Buhūth wa'l-Dirāsāt al-'Arabiyya wa'l-Islāmiyya (Cairo: Dār Hajar, 2001), vol., 3. p. 161; and Ibn Jinnī, Abū'l-Fath, al-Muhtasab fì tabyīn wujūh shawādhdh al-qirā'āt wa'l-ị̂âhh 'anhā. (ed.), 'Alī al-Najdī Nāṣif, 'Abd al-Hālīm al-Najjār, 'Abd al-Fattāḥ Shalabī. 2 Vols. (Cairo: Lajnat Ihyā' al-Turāth al- 'Arabī, A.H.1387), vol.1, p. 118; Ibn Hazm, al-Muhallā fì sharh almujallā bi'l-hijaj wa'l-āthārr. (ed.) Hassān 'Abd al-Mannān. Ammān, Bayt al-Afkār, 2003, p. 679.

${ }^{71}$ Ibn Mujāhid, Kitāa al-Sab 'a fì-l-qirā'āt. (ed.), Shawqī Ḍayf. $2^{\text {nd }}$ edn., Cairo: Dār al-Ma ārif, ca. 1401/1980, p. 234.

${ }^{72}$ Ibn Qudāma Muwaffaq al-Dīn. al-Mughnī fì fiqh al-imām Aḥmad ibn Hanbal al-Shaybānī. 13 vols. (Beirut: Dār al-Fikr, 1985). Vol. 1. p. 124.

${ }^{73}$ Ibn Qudāma Muwaffaq al-Dīn. al-Mughnī fì fiqh al-imām Aḥmad ibn Hanbal al-Shaybānī. 13 vols. (Beirut: Dār al-Fikr, 1985). Vol. 1. p. 124.

${ }^{74} \mathrm{Al}$-Ṭabarī, Jāmi' al-bayān 'an ta'wīl āy al-Qur'ān. 26 vols. (ed.), Abd al-Muḥsin al-Turkī in association with Markaz al-Buhūth wa'l-Dirāsāt al-'Arabiyya wa'l-Islāmiyya (Cairo: Dār Hajar, 2001), vol. 7. pp. $80 \mathrm{f}$.

${ }^{75}$ Al-Ṭabarī, Jāmi al-bayān 'an ta'wōl āy al-Qur'ān. 26 vols. (ed.), Abd al-Muhsin al-Turkī in association with Markaz al-Buhūth wa'l-Dirāsāt al- Arabiyya wa'l-Islāmiyya (Cairo: Dār Hajar, 2001), vol. 7. p. 80.

76 Al-Qurțubī, Abū 'Abd Allāh Muhammad al-Anșārī, al-Jāmi'lī aḥkām al-Qur'ān. 21 vols. Beirut: Dār al-Kutub al-'Ilmiyya, 1988, vol. 3, pp. 145ff.

${ }^{77}$ Ibn al- 'Arabī, Aḥkām al-Qur'ān. 3 vols. (ed.), M. A. 'Ațā' (Beirut: Dār al-Kutub al- 'Ilmiyya, 1994), vol. 1, p. 564.

${ }^{78}$ Ibn al- 'Arabī, Ahkām al-Qur'ān. 3 vols. (ed.), M. A. 'Ațā' (Beirut: Dār al-Kutub al- 'Ilmiyya, 1994), vol. 1, p. 564.

${ }^{79}$ John Burton, The Collection of the Qur'ān (Cambridge: Cambridge University Press, 1977), pp. 3637; but also note the discussions on p. 44.

${ }^{80}$ Ibn Rushd, al-Qāḍ̂̄ Abū Walīd. Bidāyat al-Mujhtahid wa nihāyat al-muqtașid. 2 vols, (ed.), A. Mu awwaḍ and A. al-Mawjūd (Beirut: Dār al-Kutub al-'Ilmiyya, 1986), vol. 1, pp. 44-46.

${ }^{81}$ Ibn Mujāhid, Kitāb al-Sab'a fì-l-qirā'āt. (ed.), Shawqī Dayf. $2^{\text {nd }}$ edn. (Cairo: Dār al-Ma'ārif. 1401/1980), pp. 182f). 
This is the Accepted Version of an article published by Springer in International Journal for the Semiotics of Law - Revue internationale de Sémiotique juridique June 2016, Volume 29, Issue 2, pp 285-311. Please refer to published version when citing, available at: $10.1007 / \mathrm{s} 11196-016-9461-1$

Accepted Version downloaded from SOAS Research Online: http://eprints.soas.ac.uk/22374/

${ }^{82}$ Al-Ṭabarī, Jāmi ' al-bayān 'an ta'wīl āy al-Qur'ān. 26 vols. (ed.), Abd al-Muhsin al-Turkī in association with Markaz al-Buhūth wa'l-Dirāsāt al- 'Arabiyya wa'l-Islāmiyya (Cairo: Dār Hajar, 2001), vol. 3. pp. 731-40.

${ }^{83}$ Al-Ṭabarī, Jāmi al-bayān 'an ta'wīl āy al-Qur'ān. 26 vols. (ed.), Abd al-Muḥsin al-Turkī in association with Markaz al-Buhūth wa'l-Dirāsāt al- Arabiyya wa'l-Islāmiyya (Cairo: Dār Hajar, 2001), vol. 3. pp. $731 \mathrm{ff}$.

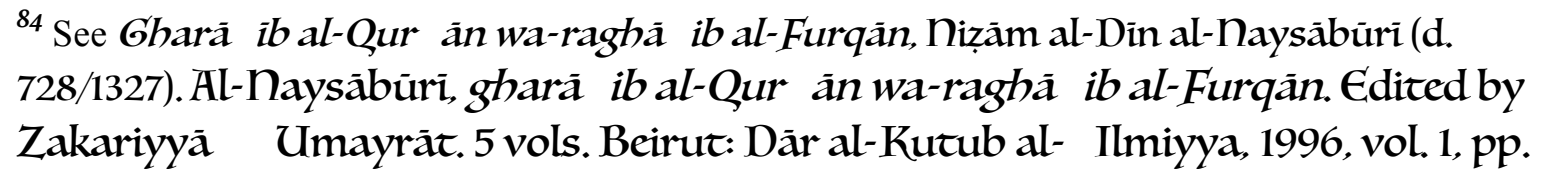
613.

${ }^{85}$ Al-Ṭabarī, Jāmi al-bayān 'an ta'wīl āy al-Qur'ān. 26 vols. (ed.), Abd al-Muhsin al-Turkī in association with Markaz al-Buhūth wa'l-Dirāsāt al-'Arabiyya wa'l-Islāmiyya (Cairo: Dār Hajar, 2001), vol. 3, p. 732 .

${ }^{86}$ Al-Qurțubīi, Abū 'Abd Allāh Muḥammad al-Anșārī, al-Jāmi' lì ahkām al-Qur'ān. 21 vols. Beirut: Dār al-Kutub al- 'Ilmiyya, 1988, vol. 2. [pt. 3], pp. 54-61.

${ }^{87}$ Al-Qurțubī, Abū 'Abd Allāh Muḥammad al-Anșārī, al-Jāmi' lī aḥkām al-Qur'ān. 21 vols. Beirut: Dār al-Kutub al-'Ilmiyya, 1988, vol. 2 [pt. 3], pp. 54-61.

${ }^{88}$ Abū Hayyān al-Gharnāṭī, Tafsīr al-Baḥr al-muḥịt. 7 vols, (ed.), 'Ādil Aḥmad 'Abd al-Mawjūd and al-Shaykh 'Alī Muḥammad Mu awwaḍ. Beirut: Dār al-Kutub al-'Ilmiyya, 1993, vol. 2, p. 178.

${ }^{89}$ Ibn Rushd, al-Qāọ̄i Abū Walīd. Bidāyat al-Mujhtahid wa nihāyat al-muqtașid. 2 vols, (ed.), A. Mu 'awwạ̣ and A. al-Mawjūd (Beirut: Dār al-Kutub al-'Ilmiyya, 1986), vol. 1, p. 17.

${ }^{90}$ Ibn Mujāhid, Kitāb al-Sab 'a fî-l-qirā'āt. (ed.), Shawqī Dayf. $2^{\text {nd }}$ edn., Cairo: Dār al-Ma ārif, ca. 1401/1980, pp. 342-43. Cf. Abū 'Abd Allāh al-Ḥusayn ibn Aḥmad Ibn Khālawayhi, Mukhtaṣar fì shawādhdh al-Qur'ān (Cairo: Maktabat al-Mutanabbī, n.d.), p. 37.

${ }^{91}$ Al-Ṭabarī, Jāmi al-bayān 'an ta'wīl āy al-Qur'ān. 26 vols. (ed.), Abd al-Muḥsin al-Turkī in association with Markaz al-Buhūth wa'l-Dirāsāt al- Arabiyya wa'l-Islāmiyya (Cairo: Dār Hajar, 2001), vol. 8. pp. 191-95. The issue of al-Tabarî̀s endorsing the wiping perspective became a controversial issue, although it is evident that he was able to reconcile the action of washing and wiping with reference to the reading. See Ibn al-Jawzī, Abū'l-Faraj Jamāl al-Dīn, al-Muntazam fì tă 'rīkh al-umam wa'l-mulūk. 18 vols., (ed.), Muhammad Ațầ' and Muștafā Ațā' (Beirut: Dār al-Kutub al-'Ilmiyya, 1992), vol. 13, pp. 215-17. See Mustafa Shah 'Al-Ṭabarī and the Dynamics of tafsìr: Theological Dimensions of a Legacy'. Journal of Qur'anic Studies. Jun 2013 (volume 15. 2), pp. 83139 , p. 101.

${ }^{92}$ Al-Ṭabarī, Jāmi al-bayān 'an ta'wīl āy al-Qur'ān. 26 vols. (ed.), Abd al-Muhsin al-Turkī in association with Markaz al-Buhūth wa'l-Dirāsāt al-'Arabiyya wa'l-Islāmiyya (Cairo: Dār Hajar, 2001), vol. 8. P. 199. 
This is the Accepted Version of an article published by Springer in International Journal for the Semiotics of Law - Revue internationale de Sémiotique juridique June 2016, Volume 29, Issue 2, pp 285-311. Please refer to published version when citing, available at: $10.1007 / \mathrm{s} 11196-016-9461-1$

Accepted Version downloaded from SOAS Research Online: http://eprints.soas.ac.uk/22374/

${ }^{93}$ Al-Qurțubī, Abū 'Abd Allāh Muhammad al-Anșārī, al-Jāmi' lì ahkām al-Qur'ān. 21 vols. Beirut: Dār al-Kutub al-'Ilmiyya, 1988, vol. 3 [pt. 5], pp. 58-72; Ibn al- 'Arabī, Ahkām al-Qur'ān. 3 vols. (ed.), M. A. 'Ațā̄' (Beirut: Dār al-Kutub al- 'Ilmiyya, 1994), vol. 1. p. 17; al-Shāfi 'ī, Muhammad ibn Idrīs, Kitāb al-Umm. 8 vols. (Beirut: Dār al-Fikr, 1989), vol. 1, pp. 42-43.

${ }^{94}$ al-Naḥhās, Abū Ja far. I'rāb al-Qur'ān. 5 vols. (ed.), Zuhayr Ghāzī Zāhid. 3rd edn. Beirut: 'Ālam al-Kutub, 1988, vol. 2, pp. 9-10.

${ }^{95}$ John Burton, The Collection of the Qur'ān (Cambridge: Cambridge University Press, 1977), p. 186 and the related discussion earlier in the text: p. 36; the same aspect to the subject was explored in a related article: John Burton 'The Vowelling of Q. 65:1', Journal of Semitic Studies, 1984, pp. 267283 , see pp. $267-8$.

${ }^{96}$ Al-Jașșạ̄, Abū Bakr, Ahkām al-Qur'ān, 3 vols. (ed.) 'Abd al-Salām Shāhīn. (Beirut: Dār al-Kutub al-'Ilmiyya, 1994), vol. 2. p. 577.

97 Al-Jașșạ̄s, Abū Bakr, Aḥkām al-Qur'ān, 3 vols. (ed.) 'Abd al-Salām Shāhīn. (Beirut: Dār al-Kutub al-'Ilmiyya, 1994), vol. 2. p. 577.

${ }^{98}$ Al-Qurțubī, Abū 'Abd Allāh Muhammad al-Anșārī, al-Jāmi' lī ahkām al-Qur'ān. 21 vols. Beirut: Dār al-Kutub al-'Ilmiyya, 1988, vol. 3. [pt. 5], p. 89.

${ }^{99}$ Al-Sarakhsī, Ușūl al-Sarakhsī, 3 vols, (ed.), Abū'l-Wafā' al-Afghānī. Hyderabad: al-Lajna al'Ilmiyya li-Ihyyā' al-Ma ārif al-Nu'maniyya. 1993, vol, 2. pp. 81-82.

${ }^{100}$ al-Zarkashī, Badr al-Dīn Muḥammad ibn Bahādir. Al-Bahrr al-muhīt fí uṣūl al-fiqh. 6 vols., (ed.), 'Abd al-Qādir al-' Ānī (Kuwait: Wizārat al-Awqāf Wa'l-Shu'ūn al-Islāmiyya, 1992), vol. 1. pp. 47480 .

${ }^{101}$ Mustafa Shah, 'The Quest for the Origins of the Qurra' in the Classical Islamic Tradition'. Journal of Qur'ānic Studies (Edinburgh University Press) (2005:7.2), pp. 1-35, p. 29 (f/n 79); Al-Urmawī, Sirāj al-Dīn Maḥmūd. al-Taḥșìl min al-maḥṣūl. 2 vols. (ed.), 'Abd al-Ḥamīd and Abū Zunayd (Beirut: Mu'assasat al-Risāla, 1988), vol, 2. pp. 18-19; Ibn Ḥazm, Abū Muḥammad 'Alī ibn Aḥmad. al-Ihkām fì uṣūl al-aḥkām. 2 vols., parts I-VIII, (Cairo: Dār al Ḥadīth, 1984), vol.1. p. 466; Al-Jașṣaș, Abū Bakr, Ahkām al-Qur'ān, 3 vols. (ed.) 'Abd al-Salām Shāhīn. (Beirut: Dār al-Kutub al- 'Ilmiyya, 1994), vol. 1, p. 537.

102 John Burton, The Collection of the Qur'ān (Cambridge: Cambridge University Press, 1977), pp. 34-36. 